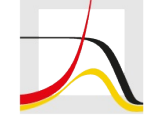

MAX PLANCK INSTITUTE

FOR DEMOGRAPHIC RESEARCH

Konrad-Zuse-Strasse 1 · D-18057 Rostock · Germany · Tel +49 (0) 3812081 - 0 · Fax +49 (0) 3812081 - 202 · www.demogr.mpg.de

MPIDR Working Paper WP 2020-027 I June 2020

Revided April 2021

https://doi.org/10.4054/MPIDR-WP-2020-027

\title{
Gendered and stratified family formation \\ trajectories in the context of Latin \\ American migration, 1950 to 2000
}

Andres F. Castro T. I castro@demogr.mpg.de

Edith Y. Gutiérrez V.

This working paper has been approved for release by: Mikko Myrskylä (sekmyrskyla@demogr.mpg.de),

Head of the Laboratory of Population Health, the Laboratory of Fertility and Well-Being, and the Research Group Labor Demography

(c) Copyright is held by the authors.

Working papers of the Max Planck Institute for Demographic Research receive only limited review. Views or opinions expressed in working papers are attributable to the authors and do not necessarily reflect those of the Institute. 


\title{
Gendered and stratified family formation trajectories in the context of Latin American migration, 1950 to 2000
}

\begin{abstract}
The interdependence of migration and family formation has been studied extensively in scholarly research. Less common are studies that consider the embeddedness of this interdependence within gender and class relations. Most of the existing research includes gender and class separately as determinants of family events or transitions, instead of analyzing how the intersections of both shape full family formation trajectories. We overcome this gap by using an intersectionality framework to analyze trajectories of family formation and migration collected by the Mexican and Latin American Migration projects (1982-2016). Using retrospective information, we reconstruct full family formation and dissolution trajectories for 16,000 individuals and apply sequence and cluster analysis to define a six-category typology of ideal family formation trajectories. Furthermore, we associate this typology with individuals' sex, age at migration (internal, international), and educational attainment. Our results suggest that the relationship between migration and typical family trajectories depends mainly on class and gender, positioning migration as a secondary disruptive factor. Family trajectories among socially and economically privileged individuals do not seem to be affected by migration; patterns by class are clearer for women than men, which signals that women's trajectories are more rooted in their social class than those of their male counterparts.
\end{abstract}




\section{Introduction}

A key insight of family and stratification research is that the interdependence of life events (e.g., entering a union, having children) contributes to the perpetuation of social inequalities (Furstenberg 2008; McLanahan and Percheski 2008). In addition, decades of research on migration in the Americas have underlined the fact that migration and family formation should be examined jointly (Coubes, Solis, and Zavala de Cosio 2016; Lindstrom, Hernandez-Jabalera, and Giorguli Saucedo 2021; Sana and Massey 2005). While it is well-known that, in Latin American and Caribbean (LACar) societies, the unequal unfolding of family and migration events contributes to widening gender gaps and class distances (Frank and Heuveline 2005; González-Ferrer et al. 2018; Parrado and Flippen 2005), scholars' capacity to frame these two life course processes as embedded in class and gender relations jointly is less advanced. The lack of a systematization of family formation and dissolution trajectories (family trajectories herein) is partly responsible for this gap in the literature.

The explanatory frameworks adopted by previous studies on migration and family focus on homogeneous or "mean" social outcomes, overlooking heterogenous paths and vulnerable groups. For us, the interaction of class and gender is a key point to understanding migration and family formation as interdependent life course-defining processes. Instead of testing the "common explanatory hypotheses" on how migration relates to family patterns, namely socialization, selection, disruption, and assimilation/adaptation (Adserà and Ferrer 2015), we rely on intersectionality theory to develop a bottom-up inductive analysis of family trajectories, one that links the interdependence of life events with class and gender differences in family and migration patterns. Intersectionality theory offers a conceptual framework to explain how gender and class relations jointly shape the interdependence of family formation and migration 
trajectories (Crenshaw 1991). We only borrow four key concepts of this theory because our data and position as researchers prevent us from engaging with its entire scope (Hill Collins and Bilge 2016:2). Specifically, we focus on inequalities and complexities of the family formation process,

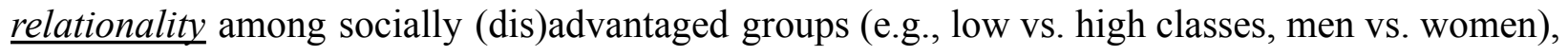
and the power relations between these groups.

We examine the inequality in the processes of family formation and dissolution by looking at individuals' sequences of marital status and the number of children born from ages 15 to 39 . These sequences allow us to focus on processes (as opposed to single events) and highlight the complexity of the life course. Because family formation and migration are structurally different for each sex, we analyze men and women separately and focus on the interaction of multiple socioeconomic and migration variables, such as age at migration, type of migration, and educational attainment (as a proxy for social class). The interaction of these variables allows us to study groups with different degrees of intersecting vulnerabilities, socioeconomically speaking, ranging from low-/uneducated young women who migrate to escape poverty, to adult migrants whose migration trajectories are associated with higher education and specialized training. This multiple-group approach reflects the relational aspect of intersectionality thinking: what matters the most in understanding the significance of a phenomenon within a socially vulnerable group is how that very same phenomenon occurs differently in other groups (including the socially privileged) and how this difference reflects power relations (Choo and Ferree 2010).

We pool all the waves of the Mexican and Latin American Migration projects (MMP and LAMP) with harmonized information on family and migration up to 2016. These data are well suited for our study, as they provide rich retrospective information on family and migration for a large 
number of men and women from diverse origins. The data cover eight countries, more than 200 local communities, and collect information on migrants in the United States (US), Spain, and Canada. ${ }^{1}$

The contribution of this paper is twofold. First, we offer an in-depth description of family trajectories in LACar countries. Along with a few studies on migrants in European countries (di Belgiojoso and Terzera 2018; Kleinepier, de Valk, and van Gaalen 2015; Kraus 2019) and studies that focus on Mexico (Coubes et al. 2016:8), ours is the first study to analyze full family trajectories in several LACar countries. Second, we provide an intersectionality-driven interpretation of the relationships between migration and family trajectories by class and gender. We use this interpretation to reassess the "common explanatory hypotheses" and change the narrative of the mean differences in family events by separate socioeconomic and demographic variables to a full heterogeneous spectrum of relations between gender, class, and migration, developing diverse and unequal family trajectories.

\section{Background}

Family and migration in LACar

During the second half of the $20^{\text {th }}$ century, LACar countries experienced significant fertility decline and growing cohabitation and marital instability (García and de Oliveira 2011; Guzmán et al. 2006). These changes were related to several factors, including the increasing participation of women in domestic and international migration flows (Donato 2010). Changes in fertility preferences, better access to information and contraceptive methods, and financial constraints contributed to depressing fertility among migrants (Adserà and Menendez 2011; Castro Martin

\footnotetext{
${ }^{1}$ Detailed information about the selection of communities is available on the projects' websites: https://lamp.opr.princeton.edu/home-en.htm and https://mmp.opr.princeton.edu/home-en.aspx.
} 
and Juarez 1995). In addition, the higher participation of women in migration created complex gender relations, as women gained financial independence from men and were exposed to relatively more gender-egalitarian contexts (e.g., cities) compared to their places of origin. These changes permeated both the migration experience and the unfolding of family trajectories (Herrera 2008; Hondagneu-Sotelo 1994; Pedraza 1991).

During the 1960s and 1970s, rural to urban migration dominated domestic migration flows in LACar (Rodríguez Vignoli and Busso 2009). This extensive urbanization was a primary factor in fertility decline (Guzmán 1996). Completed fertility among rural migrants was between that of rural and urban stayers. Scholars explained this result in terms of four hypotheses: selection, socialization, disruption, and assimilation/adaptation (Hervitz 1985; Macisco and Myers 1975; Montgomery et al. 2003:6; Zárate and Unger De Zárate 1975).

The selection hypothesis posits that fertility is lower among rural-to-urban migrants than non-migrants at origin because the former are a specific group whose fertility behavior and preferences resemble those of the destination population. In the adaptation/assimilation hypothesis, lower fertility among migrants is considered to be the result of different living and working conditions at destination, such as the higher opportunity cost of childbearing compared to labor market participation. However, fertility among rural migrants is never as low as that of urban stayers. Hence, in the socialization hypothesis, the social environment that dictates fertility behavior is that of the origin. Finally, the disruption hypothesis suggests that migration interferes with the realization of fertility preferences due to family separation.

During the same period, emigration rates from LACar countries to the US, Canada, and some European countries grew sustainably (Castles, De Haas, and Miller 2014). These migration flows were also fueled by internal armed/violent conflicts, such as the Colombian, Nicaraguan, and 
Mexican confrontations (Alvarado and Massey 2010; Donato et al. 2010; Massey and Capoferro 2006). Persistent economic development gaps between origin and destination countries and international migration policies (e.g., Bracero program) helped to consolidate these migration streams (Fussell 2010; Massey, Durand, and Pren 2014)

The research on family and international migration also finds that migration and family formation are connected and that the four explanatory hypotheses are complementary (Kulu 2005). Lindstrom and Giorguli-Saucedo (2007) have documented the way in which the temporal separation of Mexican couples due to migration depresses fertility by disrupting family formation schedules. Parrado (2011) has shown that period fertility rates overestimate Hispanic fertility due to the connection between migration and the transition to first birth. However, he also shows that differences in completed fertility between foreign- and native-born women of Hispanic origin are negligible, meaning that there are indications of assimilation/adaptation. Adserà and Ferrer (2014) have demonstrated that, in Canada, fertility rates are low before migration and high one year after, signaling that migrants delay fertility depending on their migration plans. Although all these studies find evidence of disruption and adaptation, differences across migrants' origin have also led some authors to give validity to the socialization hypothesis. This is the case with African groups in Spain and some LACar women in the US (González-Ferrer et al. 2017; Kulu and González-Ferrer 2014; Parrado and Morgan 2008; Stephen and Bean 1992).

Despite the overall consistency of these explanations, what is misleading about this narrative is the disconnection of individuals from their gender and social class and the lack of attention paid to the intersection of these two factors as structural components. As noted by De Haas (2014) and Garip (2012), hypothesis-driven accounts about migrants reconstruct the story of an 
"average" individual, paying little or no attention to the fundamental markers of migrants' social position. We argue that, accounting for class and gender, intersectionality theory hints at the answers to questions such as: how does socialization vary across class and gender; how does selection operate in origin countries and what are its consequences for family trajectories; which groups are more affected by migration-related disruptions; and who are the individuals with a greater need to adapt their family trajectories? We do not aim to provide a one-to-one relation between social groups and hypotheses in the form of " hypothesis $X$ is valid for individuals of sex $Y$ and social class $Z$." Rather, we offer a discussion on how these hypotheses make or do not make sense for some groups, whilst also pointing out their blind spots.

\section{The intersection of class and gender in LACar}

The relationship between socioeconomic inequalities and family trajectories in LACar is strong; early and high fertility trajectories are associated with negative socioeconomic outcomes and deprived living conditions, whereas the reverse is true for family trajectories of delayed and low fertility (Juarez and Gayet 2014). Studies have shown that low-educated women accelerate the transition to childbearing, whereas the reverse is true for highly educated women (Lima et al. 2018). These dynamics have been in place since the beginning of the fertility transition in virtually all LACar countries (Chant and Mcllwaine 2009:9; Urdinola and Ospino 2015).

The timing of family formation also shows important differences by gender in LACar countries. Despite modest declines, the age difference within a couple continues to favor men. By starting families later, men have more time to accumulate assets, labor market experience, and educational degrees compared to women. Once part of a couple, women are expected to undertake most of the care work at home, and they are often underemployed; men are 
responsible for the financial support of the household and typically have better jobs (García and de Oliveira 2011; Urdinola and Tovar 2017).

Furthermore, international mobility is more restricted for women than men. When they intend to migrate, women depend more on family and kinship networks compared to men (Curran and Rivero-Fuentes 2003). Hagan (1998) has shown that the residential isolation of female domestic workers prevents Mayan migrant women from developing horizontal relationships with non-Mayan individuals, which translates into less social and cultural capital to interact with US institutions. This is not the case for men, who are disproportionately employed in occupations that do not isolate them. These sex differences are present in virtually all dimensions of the migration experience, including the timing of migration, the destination, and the decision-making and labor division within a household (Donato 2016; Hondagneu-Sotelo 1994; Massey, Fischer, and Capoferro 2006). There are instances when migration favors women's empowerment and financial independence, as they are more likely to join the labor market and become more aware of their potential (Hondagneu-Sotelo 1992; Parrado and Flippen 2005). Nevertheless, aggregate trends at origin and destination suggest that negative consequences override positive ones, translating into worse socioeconomic and labor conditions for women. This situation is especially true for women from lower socioeconomic backgrounds (Herrera 2013; Sassen-Koob 1984).

\section{Analytical approach}

We rely on two assumptions and one hypothesis that incorporates multiple relationships between family and migration. This hypothesis refers to the overarching patterns in the relationships between migration and family by class and gender. Furthermore, our bottom-up statistical 
analysis makes the study partially inductive and fundamentally different from deductive approaches to hypothesis testing.

\section{Assumptions}

Our primary assumption is that migration and family formation are embedded in class and gender relations. Whether family formation occurs before or after migration and the way in which a family trajectory unfolds vary across social classes and gender because both processes are determined by individuals' opportunity structures. Class-specific family trajectories may preclude or encourage migration as much as class-specific migration opportunities limit the family trajectories of potential migrants. This assumption implies that the family strategies migrants follow to cope with new living conditions at destination vary according to migrants' class and gender. As family formation occurs earlier among women than men, especially among those from lower classes, migration could further accentuate class differences among the former. An important branch of the gender literature on migration in LACar has shown that lower class women migrate before age 18 , without being fully supported by their parents, if they are married to an older male migrant (Herrera 2012). Their life experience and opportunities are substantially different from those of higher class women who migrate as daughters within economically and socially advantaged families. Thanks to their families' support, this latter group of women has better socioeconomic opportunities before, during, and after migration. This unequal distribution of opportunities is more true in the context of international than internal moves because gender roles, labor market conditions, and migration policies have historically favored male migration (Landale and Oropesa 2007). ${ }^{2}$

\footnotetext{
${ }^{2}$ The Dominican Republic constitutes an exception, given that women are more likely to have the role of providing financial support for the household. Consequently, they are more likely to be the leaders of the household's migration strategy.
} 
Our second assumption states that international migration is more disruptive than domestic. This hierarchical relation is not necessarily true in general; however, for the LACar context during the period of analysis, we can assume that international migration is riskier, requires more resources, and implies more contextual changes than internal. Therefore, international migration may imply more extended periods of separation from family members and more uncertainty within couples. Formal marriage may facilitate international migration or be a requirement for family reunification. In contrast, domestic migration is less affected by high risks and costs in the sense that, in principle, distances are shorter, return migration more affordable, re-migration less risky, and family reunification subject to fewer or no legal constraints (Curran and Rivero-Fuentes 2003). Well-established migrant networks may decrease the cost and risk associated with international migration and even facilitate circular migration (Fussell 2010; Massey 1990); however, this does not negate the main difference between internal and international migration.

\section{Hypotheses}

Our main and secondary hypotheses describe the expected associations between vulnerability, along the lines of class and gender, and the disruptions implied by internal and international migration to individuals' family formation trajectories.

H1: The relationship between migration and family paths is not unique; it is contingent on an individual's socioeconomic and demographic characteristics, in particular on those related to intersecting social vulnerabilities/privileges. These intersections determine the socially (dis)advantaged position of individuals and therefore influence their opportunity structure to follow specific family trajectories. Socially privileged and socially disadvantaged migrants are expected to follow distinct family trajectories. 
H1.1: The patterns described in H1 will be clearer among women than men. Men's privileged position in terms of mobility makes their family formation trajectories less dependent on their socioeconomic and demographic characteristics, including their socioeconomic background and age at migration.

H1.2: The patterns described in H1 will be clearer among international than internal migrants, due to the stronger disruptive potential of the former. In addition, the expansion of class and gender gaps associated with migration will be larger among the former type of migrants compared to the latter. ${ }^{3}$

\section{Data and methods}

\section{Data sources and comparability}

We use data from the Mexican and Latin American Migration projects (MMP and LAMP). The shared methodological and theoretical basis of these two projects makes them highly comparable (Massey and Zenteno 2000; Riosmena 2016). The most substantial advantage of these projects is their ability to capture the history and heterogeneity of migration dynamics across LACar countries (Massey and Riosmena 2010). Although the LAMP in South America collects information about migrants in Spain, Canada, and the US, the former destination is more significant than the latter two. Likewise, the MMP and the LAMP in Central America collect information on migrants in Canada, although the vast majority of migrants during this time period are in the US.

\footnotetext{
${ }^{3}$ An exception to this hypothesis are internally displaced populations. Among these populations, family disruptions due to migration could be considerable due to crime and armed conflict. However, the samples of the MMP and LAMP do not collect specific information on these phenomena or the reasons for migrating.
} 
Data collection years and sampling areas also vary across countries. The MMP has run on a yearly basis since 1982, and it had a rural focus during the first few years. However, some urbanized areas (e.g., from the state of Jalisco) were included in the project as early as 1982 . The LAMP samples span from 1999 to 2016, and, for South America, they are mainly derived from urban areas. We use the Mexican data until 2016. The other countries with harmonized birth and marital histories for household heads and migration histories for household heads and spouses/partners are Colombia (2008, 2016), the Dominican Republic (1999, 2000), Ecuador (2012), Guatemala (2004), Nicaragua (2000, 2002), and Peru $(2001,2005)$.

The rationale underlying our decision to pool these data is based on the "maximum differences" design (Przeworski and Teune 1982). If similar patterns appear among migration streams of different size and stages of development, this will imply greater significance compared to if the patterns were observed among a more homogeneous set of migration streams. Family and migration trajectories across these LACar countries are still comparable given the relative uniformity of these countries in terms of overarching family patterns (Esteve and Lesthaeghe 2016), class structures (Castro Torres 2020; Portes and Hoffman 2003), and position within worldwide migration systems (Organization of American States 2011). A recent study on family formation, fertility, and migration has proven the fruitfulness of pooling data across these migration streams (Lindstrom et al. 2021).

Finally, the local representativeness of the MMP and LAMP requires some comments. Part of the households is a random sample from local communities with high emigration rates in origin countries. Data are collected during the end of the year, the time when migrants are likely to be visiting their families. The remaining households are incorporated into the data through a snow-bowling sampling strategy at destinations. Due to these collection strategies, the data are 
biased towards returning migrants with strong family ties and who presumably have more stable family trajectories.

\section{Family formation and dissolution trajectories}

Our outcomes of interest are sequences of individuals' family statuses from ages 15 to 39 . Family statuses are the combination of four marital status categories (never married, married, cohabiting, and separated/divorced/widowed) and four parity groups (zero, one, two, and three or more). Table 1 displays the number of individuals for whom family trajectories are available by sex, type, and age at migration. The sample sizes by age at migration are indicative of the feasibility of disaggregated analysis by educational attainment across these groups.

\section{TABLE 1 ABOUT HERE}

Due to differences in the collection times across countries and increasing sample sizes over time, most of the individuals in the sample were born between 1950 and 1969 (lower panel in Table 1). ${ }^{4}$ The family trajectories among the 1950-1969 birth cohorts are more comparable than the overall sample because family patterns were relatively homogeneous among these birth cohorts (Fussell and Palloni 2004). This means that our results are unlikely to be driven by the differences between older $(<1950)$ and younger $(>1970)$ cohorts. Robustness checks are included in the appendix.

Because we do not have the marital and birth histories of household heads' partners/spouses ( $81 \%$ of the women and $1.8 \%$ of the men, according to Table 1$)$, we assume that they have the same family trajectory as their partner/spouse who is the household head, only adjusting their age difference. This assumption is not problematic for individuals who entered marriage/union at

\footnotetext{
${ }^{4}$ Table A1 displays full disaggregation of the sample by sex, birth cohort, and type of migration.
} 
early ages and did not divorce/separate, as they do share family trajectories. In our sample, $88 \%$ of individuals did not report divorces or separations; the median age at marriage was 21 for women and 24 for men (unweighted). This means that, for a large share of our sample, the assumption of shared family trajectories is not especially problematic.

In the remaining $12 \%$ of the cases, where individuals report divorce, separations, and/or remarriage, assuming shared family trajectories between household heads and spouses/partners may be incorrect. First unions/marriages and divorces/separations may not be included in the data, and a stable family trajectory may be incorrectly assumed. Hence, these spouses/partners' family paths are biased towards more stable family trajectories. Additionally, given that most of the household heads are men, assuming shared family trajectories between household heads and spouses may undermine gender differences. These two potential biases make our results a conservative estimate of the actual differences by sex. We conduct a separate analysis of the family trajectories of household heads (1,526 women and 8,013 men), and the results were consistent.

\section{Explanatory variables}

The explanatory variables are type of migration, age at migration, and educational attainment. Results for men and women are yielded separately and interpreted jointly, in order to illuminate gender differences.

Individuals are classified as non-migrants if they do not report domestic or international moves. We classify international trips as migration moves if they lasted at least three months and involved work or an active job search. We sum the time of all these trips for each individual; if the cumulative time spent abroad is at least 12 months, we classify the individual as an 
international migrant. ${ }^{5}$ For domestic moves we rely on information about the year of occurrence and duration of the first move. We calculate the age at migration as the difference between the year of the first migration and the year of birth and code it into four groups: <18, 19-24, 25-34, and $34+$.

Individuals who report both international and domestic migration are considered international migrants for two reasons. First, international migration has greater implications for family trajectories than domestic migration. These greater implications are associated with the distance between the countries of study, the costs of migration, and the legal requirements for migrating, returning, and staying. Second, the sample size does not allow us to separately analyze individuals who migrate both internationally and domestically (1,010 men and 233 women refer to Table A1). Additionally, in $25 \%$ of these cases, domestic migration occurred after international, suggesting that domestic moves are the first step in an international migration trajectory (Figure A1).

Educational attainment is separated into four categories of years of schooling (y.s.): 0-4 (lowest), 5-8 (low), 9-12 (medium), and 13+ (high). Fewer than four years of schooling only ensure basic literacy and numeracy skills, while five to eight years imply basic competence for manual jobs. Nine to 12 are roughly equivalent to high school completion in the US system, and more than 12 years indicate at least some college education. This variable is a good measure for social class because the correlation between educational attainment and class position in LACar is strong (De Ferranti et al. 2004:6), a correlation also observable in our data. For example, most women with fewer than four y.s. are out of the labor force (68\%), potentially working in the informal

\footnotetext{
${ }^{5}$ This classification is appropriate for this study because it does not consider short trips and visits to family members as migration. Also, the process of settlement is more likely to occur among people who have lived abroad for at least one year, compared to people with only a few months of migration. There are 92 women and 387 men who have lived abroad for less than a year.
} 
economy. This figure is only $24 \%$ among women with at least 13 y.s. For men, the modal occupations for each educational attainment group are Primary occupations in agriculture and mining (0-4 y.s.), Skilled manual occupations (5-8, and 9-12 y.s.), and Education and professional (13+ y.s.).

\section{Intersectional social groups and data analysis steps}

The interaction of these explanatory variables yields 72 groups (two types of migration, four age at migration groups, one group of non-migrants, four educational attainment categories, and two sexes). The examination of family trajectories across these groups uncovers the inequalities, complexity, and power dynamics involved in these two demographic processes. In line with Crenshaw (1991), this approach does not aim to create a totalizing theory of family formation in migration contexts. We focus on explanatory variables that matter in the case of LACar migration specifically, and we are aware that some other potentially important dimensions are omitted.

We follow a three-step partially inductive data analysis strategy. First, we use sequence and cluster analysis (SA/CA) techniques to create a family typology that minimizes the within-category variance of individual family trajectories and makes categories maximally distinct (i.e., maximizes between-category variances). Specifically, we apply the Ward method to a pairwise individual-level dissimilarity matrix calculated via Optimal Matching (OM). To account for the timing and qualitative differences across family statuses, we adjust OM measures, using Lesnard (2010) and Gower's (1971) approaches, respectively (Studer 2013). ${ }^{6}$

\footnotetext{
${ }^{6}$ Specifically, the dissimilarity between sequences is measured as the minimum transformation cost to make two sequences identical via substitution operations. To account for the timing of events and qualitative differences across family statuses, substitution operations are weighted by the inverse of age-specific transition rates and the Gower dissimilarity index for family statuses, respectively.
} 
We choose a six-group partition based on the proportion of explained variance, and we consolidate this clustering by using the K-means algorithm (Kaufman and Rousseeuw 1990).

Second, we use multinomial models to estimate the conditional distribution of the family typology across the 72 groups described above. We control for birth cohort groups $(<1950$, 1950-59, 1960-69, and >1970) and regions (Central America, South America, and Mexico) to account for changes over time and differences across regions and migration streams in family patterns and sample sizes. We use the expression "family profiles" to refer to these conditional distributions. ${ }^{7}$ In the third step, we extract and display the main patterns and uncertainty among family profiles by applying a Principal Component Analysis to a table that appends 500 replications of the 72 family profiles. The replications are based on the predicted probabilities and the standard errors estimated by the multinomial models (Genz and Bretz 2009).

We are aware this analytical strategy does not account for all elements of intersectionality theory. Quantitative approaches are severely limited in some important respects. However, SA/CA accounts for the complexity of the family formation process and maximizes the inequality between family trajectory types. Additionally, the PCA plots emphasize relationality and power. These plots ultimately show where socially disadvantaged and socially privileged groups - in terms of class, gender, and age at migration - stand with respect to each other based on their multinomial model propensities to follow certain family paths, rendering a visual representation of the social relations underlying family formation dynamics possible. This is not merely an appropriate approach to operationalizing these concepts, but also one that is helpful for

\footnotetext{
${ }^{7}$ We use standardized weights at the country-wave-level in steps one and two, so that each country-wave has the same total influence on the analysis. This is important given the overrepresentation of Mexican individuals in the sample. In addition, the model specification, which includes dummy variables for birth cohort groups and regions, yields a $2 \%$ lower AIC compared to a model without these dummy variables, signaling a better fit.
} 
understanding the implications of migration beyond the description of the "average migrant's" experience.

\section{Results}

Prevalence of migration by sex and the class background of migrants

According to the left panel in Figure 1, emigration rates from LACar countries to Canada, Spain, and the US were growing since 1970, in particular among our countries of focus (colored-bolded lines). Emigration rates were higher in Central America and Mexico than South America due to the long history of the former migration streams, but South American nations display very similar growth trends over time. As for the sex composition of the migrant population (right panel), South American migration flows changed from being male-dominated, in 1960, to slightly female-dominated in the 2000s. The opposite trend is observed in Central America, with the exception of the Dominican Republic, where women outnumbered men throughout the entire period. These growing and diversifying trends speak of the diversity of international migration flows in LACar.

\section{FIGURE 1 ABOUT HERE}

Sex differences in international migration prevalence are larger in the MMP and LAMP than in Figure 1, reflecting the gendered nature of mobility in LACar emigration communities. According to Table 2, only $12 \%$ of women migrated to another country, whereas roughly one in three men did so (p-value $<0.01$ ). Instead, the prevalence of domestic migration (approx. 27\%) is indistinguishable between the sexes.

TABLE 2 ABOUT HERE 
The pattern of statistically significant differences (bolded values, Table 2) in the educational profiles by migration status suggests that migrants are positively selected, meaning that their class backgrounds are more privileged than those of non-migrants. As most of the domestic moves occur before age 25 (approx. 70\% ), internal mobility is positively associated with better educational opportunities at destination. This positive association between domestic migration and education does not negate sex differences in the latter. Among non-migrants, the sex ratio in the proportion of individuals with higher education is $14.9 / 9.7=1.53$ ( $\mathrm{p}$-value $<0.01)$, meaning that men are $53 \%$ more likely to pursue higher education than women. This ratio is smaller, 1.36 (p-value $<0.01$ ), but it still favors men among domestic migrants.

In contrast, in the case of international moves, sex differences in the flow selection favor women: $20.3 \%$ of international migrant women have at least 12 y.s. Men are negatively selected in international migration flows, with $59.3 \%$ having only up to four y.s. This different selectivity implies that migrant women are more likely to be from higher social classes, both compared to men and to non-migrants. These selection patterns reappear across age-at-migration groups, in particular among young adult migrants (see Table A2).

\section{Family typology and family profiles}

The six categories of the family typology differ in terms of number of events (unions, births, separation/divorces), something we refer to as intensity, and the degree of deviation from a "normative" family path (i.e., early transition to a unique and stable marriage). By using the term "normative," we want to emphasize the fact that there is a large group of individuals with family trajectories of unique and stable marriages, which makes the phenomenon a tacit societal norm. 
Figure 2 displays individual family trajectories and typologies for women and men. The distribution of men and women in this typology represents the family profile of the LACar communities studied.

\section{FIGURE 2 ABOUT HERE}

The bottom area of the plot contains the three categories of low intensity family events and delayed transitions to union formation and childbearing, i.e., lower prevalence of marriage and union formation, late marriage, and low fertility. The top area comprises the one category of high intensity family events (multiple births, divorces and marriages). The central area includes two "atypical" family trajectories (unstable and lifelong cohabitation).

These typologies account for $84.5 \%$ and $85.8 \%$ of the variance of the individual family trajectories of women and men, respectively. This means that our SA/CA successfully creates internally homogeneous and externally distinct groups. The significance of this typology can be visually assessed by comparing Figure 2 and Figure A4, which displays individual family trajectories organized by educational attainment. Despite the strong relationship between educational attainment and family events, there are many kinds of individual family trajectories across educational categories. These categories explain less than $3.5 \%$ of the variance of the individual family trajectories for both sexes.

With $7.1 \%$ of women comprising it, "Never married" is a category of singleness and single motherhood. Only a small number of women in this category entered unions during the observation period. For all other categories, the transition to union formation is universal; this transition occurs later among the $11.5 \%$ of women in the "Delayed" category and earlier among the $20.8 \%$ and $5.4 \%$ of women in the "Norm-late" and "Unstable" categories. Virtually all 
women in the "Unstable" category are separated or divorced by age 39, and all women in the "Cohabiters" category cohabited for most of the observation time. Women in the top group move to union formation very early and have the highest completed fertility of all categories. We label this group "Norm-early" because it comprises $45.1 \%$ of women, and it is characterized by early, universal, and stable marriages. Divorces among this group are infrequent, and, when they occur, women tend to remarry.

Among men, there is no "Unstable" category; instead, an additional category of very delayed transitions to union formation and low fertility is added ("Latest"). The overall delayed schedule and the absence of the "Unstable" category among men are potentially a consequence of sex differences in the age at union formation, marriage, and childbearing. In other words, by age 39, men and women have had completely different family formation experiences, in particular in terms of early transition and union instability.

To assess how this typology and the differences by sex may be driven by the assumption about the shared family trajectories of household heads and spouses/partners, Table 3 contrasts the typology for the entire sample (rows) and the typology obtained only for household heads (columns). This table also displays the proportion of household heads in each family category. Despite substantial differences in household headship by sex $(98.2 \%$ for men and $19.0 \%$ for women), the correlations between the typologies are remarkably high for both sexes. These strong correlations suggest that the role of the assumption is relatively unimportant for women and negligible for men.

TABLE 3 AROUND HERE 
There are, however, two important differences between the typologies among women. First, the "Unstable" category is split into two categories ( $\mathrm{ft}-03$ and $\mathrm{ft}-04$, see Figure A3). This discrepancy is not problematic because $90.1 \%$ of the women in the "Unstable" category are household heads, meaning that their family trajectories are observed. A visual inspection of Figure A3 confirms that the difference between $\mathrm{ft}-03$ and $\mathrm{ft}-04$ is that the former category contains cohabiters who separated, whereas the latter groups women who were married and then divorced. In short, the "Unstable" category is a valid descriptor of the life course family experiences of women.

Second, the "Norm-late" category is merged primarily into ft-06. The absence of the "Norm-late" category among household heads is problematic. These women could have been married or in unions before marrying their current partner (i.e., the household head from whom we are borrowing the family trajectory). These previous marriages and unions are impossible to observe, which biases women's family paths towards stable and delayed trajectories, downpalying sex differences. We take this bias into consideration when interpreting the multivariate results.

An important aspect of this typology is its variation across regions, as displayed in Table 4. This table validates the typology's categories, in the sense that it does not contradict what we know about family systems in LACar, while also adding important aspects regarding the unfodling of family events during individuals' life courses (Esteve, Lesthaeghe, and López-Gay 2012; Quilodrán 2011). The aforementioned high prevalence of marriages in LACar is split into four categories that differ in terms of the timing of marriage (early vs. delayed), stability of unions/marriages (early-unstable vs. stable), and fertility levels and timing (high vs. delayed-low). Likewise, the pattern of early union formation among "Cohabiters" suggests that 
the so-called dual-regime of unions and marriages in LACar, where these two types of unions are treated as equal, may only be true for certain sub-population groups, rather than for the entire population.

\section{TABLE 4 AROUND HERE}

According to Table 4, the main difference across these three regions is the proportion of the "Cohabiters" and "Norm-early" categories, reflecting the higher prevalence of marriage in Mexico compared to the other two regions. The highest proportion of "Cohabiters" is observed in Central America, whereas South American countries display larger proportions of women and men in the "Delayed" and "Latest" categories compared to the other two regions, respectively. Differences in the other categories are smaller and non-statistically significant. These differences and the differences in the urbanization levels of sampling areas between regions require controlling for region when estimating family profiles by age at migration and educational attainment.

Intersectional heterogeneity: sex, age at migration, and educational attainment

Figures 3 and 4 display the first two factorial axes of the PCA on the 500 replications of the family profiles. ${ }^{8}$ These figures summarize $55 \%$ and $52 \%$ of the variance of the replicated family profiles of women and men, respectively. We separate internal (left) and international migrants (right) for clarity purposes. Both planes contain the non-migrant group and are interpretable jointly. Because this type of plot is not common in family and migration research, we include some comments on how to interpret it.

\section{FIGURE 3 ABOUT HERE}

\footnotetext{
${ }^{8}$ Tables A3 and A4 in the appendix display all of the 72 conditional distributions (i.e., family profiles) along with their associated standard errors.
} 
The center of the plot represents the marginal distribution of the family typology as estimated by the multinomial model. The categories of the family typology and the family profiles of all educational attainment and age at migration groups are represented by markers $(\times, \circ, \triangle, \mathbf{\square}, \bullet)$. The distribution of these markers reflects the main similarities and differences among family profiles and the associations between groups and family categories.

The proximity among family categories implies that, across the age at migration and educational attainment groups, the proportion of individuals in these categories is simultaneously high. For example, the two closest family categories in Figure 3 are "Norm-early" and "Unstable," meaning that, among groups where the proportion of women in the "Norm-early" category is high (relative to the mean), the proportion of women in the "Unstable" category is also high. This interpretation is reversed for the two most distant categories, namely "Cohabiters" and "Norm-late." Thus, the horizontal axis separates high-intensity (left) from low-intensity family categories (right). The vertical axis separates normative categories (bottom) from less/non-normative trajectories (top).

For the family profiles, the proximity between a group and a family category implies positive association; distance/separation implies the opposite. Therefore, if two groups are close to one another, their family profiles are similar; if two groups are far from one another, their family profiles differ. Non-overlapping distributions of dots provide a sense of the statistical significance of the differences in groups' family profiles, and lines connecting educational attainment levels depict social class gradients. We proceed to describe the patterns that emerged for women and men.

Higher education among women is associated with low-intensity and non-normative family trajectories ("Never married," "Delayed," and, to a lesser extent, "Norm-late"). Low education 
is associated with the "Unstable," "Cohabiters," and "Norm-early" family trajectories. The clouds of points of the highest and lowest educational attainment groups do not overlap. Importantly, these differences in family profiles across educational attainment groups are greater among domestic migrants than non-migrants. The only exception is women who migrated between ages 25-30. For them, family profiles have higher proportions in the "Never married" and "Delayed" categories for all educational attainment groups. Domestic migration also separates the family profiles of young adult migrants (19-24) from those of adult migrants. The former group is strongly associated with traditional family trajectories (bottom area) and the latter with less traditional ones. This pattern holds for all educational attainment groups.

Overall, international migration is negatively associated with cohabitation: only 2 out of the 16 groups of international migrants appear in the same quadrant as the "Cohabiters" category. Additionally, family profiles among international migrant women display more significant and less patterned deviations across educational categories compared to domestic migrants, meaning that international mobility is more disruptive than domestic and that disruptions are more heterogeneous in the former case. As educational attainment is a strong predictor of family outcomes, the disruption of educational profiles among international migrant women signals the importance of the migration experience for family trajectories. For example, among women who migrate as adolescents $(<18)$, the distance between the family profiles of the low- and highly educated is the greatest. This separation suggests the existence of two distinct family migration paths. On one side, lower educated women who did not finish high school, probably because they migrated independently, are associated with "Norm-early" and "Unstable" trajectories. On the other, women who also migrated as adolescents, but had at least some higher education, are associated with the "Never married" and "Delayed" family trajectories. 
Women who migrate between ages 19-24 are more likely to be in the "Norm-late" category. Among these women, union formation, union stability, and migration are strongly intertwined, potentially because marriage and migration occur very close to one another in women's lifetimes. Family profiles for women who migrate between ages 25-30 are strongly disrupted. These women are more likely to follow low intensity and non-normative family paths, with the exception of those who have higher education. The last age-at-migration group displays more modest deviations compared to non-migrants.

As seen in Figure 4, the factorial axes also separate low-intensity family trajectories (right) from high-intensity ones (left), as well as normative from less/non-normative trajectories along the vertical direction. However, the distribution of family profiles in the plot differs between the sexes. These discrepancies underline the significance of gender relations in determining individuals' probabilities to follow certain family trajectories in the context of migration. These correlations are extremely apparent in the analysis of our sample because, even though men and women's family trajectories are not fully independent, the results differ by sex.

Family profiles, in the context of domestic migration, display less disruption among men than women, with three critical similarities. First, differences across educational attainment levels follow the same direction for both sexes: higher education is accompanied by lower intensity and less normative trajectories. Second, late migration is associated with less intense and less normative family trajectories. Third, migration between ages 19-24 is strongly associated with normative trajectories.

FIGURE 4 ABOUT HERE 
In the international migration context, men's family profiles are strongly disrupted and less patterned than those of women, as hypothesized above. There are, however, three distinguishable patterns. Compared to their class counterparts who migrated internally, international young adult migrants (19-24) are more likely to fall into the "Norm-late" category. If we compare this result to that for young adult migrant women from lower classes (Figure 3), we see that the association between this group and the "Norm-late" category is not as strong as it is for men. Indeed, young adult migrant women with the lowest educational attainment are associated with "Norm-early" and "Unstable" family categories, emphasizing that similar social class backgrounds and age at migration may have different implications for men and women. Migration between ages 25-30 is associated with the most considerable class differences, separating highly educated men in "Delayed" category from lower educated men, who tend to follow "Norm-early" and "Cohabiters" trajectories. Finally, lower class men who migrate after age 30 display almost identical family profiles as those who did not migrate. Instead, highly educated men who migrate late are substantially more likely to be in the "Latest" and "Never married" categories, compared to their non-migrant class counterparts.

These patterns are very similar to those observed in the analysis of the 1950-1969 birth cohort. Although smaller sample sizes yield greater uncertainty in the estimates (i.e., more dispersed clouds of points), the overarching patterns in Figure A4 are highly consistent with those in Figures 3 and 4 .

\section{Conclusions and discussion}

The development of international and internal migration streams during the post-war period in LACar countries was part and parcel of the major societal transformations of the region. We capitalize the diversity of these migration streams to uncover the patterns of the association 
between the migration experiences and family formation trajectories of more than 16,000 individuals from eight countries.

The LACar case is an illustrative example of the necessity to examine how the relationship between migration and family formation varies by type of migration, both in terms of gender and across social classes. These patterns have previously been neglected by deductive research designs that overly focus on testing competing/complementary hypotheses. Instead, we propose a partially inductive approach, informed by intersectionality theory, to understand the concrete circumstances that make these hypotheses valid or not in the case of LACar. Moreover, we derive some implications for studies of international migration in other regions of the world.

Our main conclusion is very straightforward: migration is not associated with a unique family trajectory or with changes in a specific direction (e.g., delayed or accelerated family formation, higher or lower fertility, more or less marital stability); migration and family formation are tied in several ways depending on individuals' class and gender vulnerabilities and privileges. Migration can partially transform the influence of class and gender, without eliminating their structural role. Indeed, in several cases, migration can reinforce the inequality in opportunities at play due to class and gender. This conclusion suggests that migration studies throughout the world could benefit from examining how the interaction of these two factors matters for migrants' socioeconomic and demographic outcomes, including, but not restricted to, fertility and family formation. We are not the first to notice the need to use the concepts of class and gender in migration studies (Herrera 2012; Kanaiaupuni 2000; Van Hear 2014). However, we are the first to emphasize the full potential of investigating their intersection for understanding family trajectories, using quantitative information. 
The intersection of social class and gender helps us to make sense of the variety of patterns that emerge when migrants' family trajectories are inductively analyzed. Some of these patterns fit into the narratives of the socialization, selection, disruption, and adaptation hypotheses, while others do not. Instead, from an intersectional perspective, class and gender relations are structural factors that shape individuals' opportunities and aspirations to migrate and form families (and potentially achieve other socially desirable goals). Hence, differences in the opportunity structures of people across the social spectrum imply that there is no one unique socialization experience, but several, depending on class and gender. This is why the overall pattern of family profiles by educational attainment is rather similar across age at migration groups and also why differences by sex are so apparent.

Similarly, sex differences in the educational selectivity of migrants are the byproduct of sex gaps in accessing education and prevailing gender norms in LACar countries that make migration more restrictive for women than men. Gender norms in LACar associate women with family care and domestic work, for which neither higher education nor migration experience is necessary. In other words, the stronger positive selection of migrant women in terms of class background shows that it is more difficult for women to migrate internationally compared to men. Likewise, the negative selection of men is associated with recruitment policies that targeted unskilled men, encouraging them to migrate as agricultural workers, during the 1960s and 1970s. This reversed flow-selection by sex in international migration emerges from the higher constraints on women's mobility and the more favorable migration channels offered to low-educated men.

As for the hypotheses regarding disruption and adaptation/assimilation, our intersectional lens reveals that family trajectories among socially and economically privileged individuals are not affected by migration as much as they are among disadvantaged populations (e.g., young 
uneducated migrant women), underlining the role of power imbalances between classes and genders. To the extent that some of these specific trajectories (e.g., "Early-norm" and "Unstable") are associated with worse socioeconomic outcomes for parents and children, classand gender-dependent disruption and adaptations contribute to widening class and gender differences.

Despite its disruptive nature, domestic migration does not erase class and gender differences in family profiles; if anything, it accentuates them among young migrants. This conclusion does not hold for international migration. Class differences in family profiles among international migrants are disruptive and display a significant qualitative difference by sex. For women, class differences are heightened if migration takes place before age 18 and diminished when migration occurs between ages 19-24 and 25-30. For men, patterns across ages at migration and educational attainment are more erratic. These less patterned associations reflect men's privileged position in the realms of family and migration. Men's family trajectories are less affected by their social class and migration history than women's. At the very least, this result reflects scholarly incapacity to establish the appropriate socioeconomic and demographic variables that would allow clear patterns for men's family profiles to appear.

These sex differences are significant beyond the LACar case. In most countries with negative migration balances since the 1950s, men and women do not have the same opportunities to form families and migrate (Donato 2016). Family formation starts considerably earlier for women than men, and women need more resources to be able to undertake international migration. These differences have an impact on the reproduction of gender gaps in socioeconomic outcomes because women have considerably less time available for the accumulation of educational degrees and assets valuable for the labor market, a difference that is further increased by the 
disparities in the distribution of care work. To the extent that migration is also a time- and resource-consuming process, women may face twofold disadvantages, as migration-related disruptions affect a smaller baseline of their time and resources compared to men. The implications of these differences can be greater for low and middle-low class women because the timing of family formation among these two groups is the earliest.

Although we observe these patterns only for migration streams from LACar's sending communities, rising levels of economic inequality, sustained gender inequality, and the increasing diversification of migration flows worldwide (Bauman 1998; Pikkety 2019) suggest that our conclusions may apply to any migration system involving men and women from diverse socioeconomic and cultural backgrounds. Narratives based on the experiences of the "average" migrant have erroneously neglected the heterogeneity of the association between migration and family formation and have, therefore, been blind to its implications (Portes 2010). We hope to shed light on those implications and encourage more research on how intersecting forms of inequality shape demographic processes. 


\section{References}

Adserà, Alícia, and Ana Ferrer. 2014. "The Fertility of Married Immigrant Women to Canada." International Migration Review 50(2):475-505. doi: 10.1111/imre.12114.

Adserà, Alícia, and Ana Ferrer. 2015. "Immigrants and Demography." Pp. 315-74 in Handbook of the Economics of International Migration. Vol. 1A, edited by B. Chiswick and P. Miller. North-Holland: Elsevier.

Adserà, Alícia, and Alicia Menendez. 2011. "Fertility Changes in Latin America in Periods of Economic Uncertainty." Population Studies 65(1):37-56. doi: 10.1080/00324728.2010.530291.

Alvarado, Steven Elias, and Douglas Massey. 2010. "In Search of Peace: Structural Adjustment, Violence, and International Migration." The Annals of the American Academy of Political and Social Science 630(1):137-61. doi: 10.1002/ana.22528.Toll-like.

Bauman, Zigmunt. 1998. Globalization: The Human Consequences. 1st ed. New York: Blackwell.

di Belgiojoso, Elisa Barbiano, and Laura Terzera. 2018. "Family Reunification - Who, When, and How? Family Trajectories among Migrants in Italy." Demographic Research 38(1):737-72. doi: 10.4054/DemRes.2018.38.28.

Castles, Stehphen, Hein De Haas, and Mark J. Miller. 2014. The Age of Migration. Internation Population Movement in the Modern World. 5th ed. New York: The Guildford Press.

Castro Martin, Teresa, and Fatima Juarez. 1995. "The Impact of Women's Education on Fertility In Latin America: Searching for Explanations.” International Family Planning Perspectives 21(2):52. doi: 10.2307/2133523.

Castro Torres, Andrés Felipe. 2020. "Analysis of Latin American Fertility in Terms of Probable Social Classes.” European Journal of Population. doi: 10.1007/s10680-020-09569-7.

Chant, Sylvia, and Cathy Mcllwaine. 2009. Geographies of Development in the 21st Century. An Introduction to the Global South. Fist. Cheltenham: Edward Elgar Publishing Limited.

Choo, Hae Yeon, and Myra Marx Ferree. 2010. "Practicing Intersectionality in Sociological Research: A Critical Analysis of Inclusions, Interactions, and Institutions in the Study of Inequalities." Sociological Theory 28(2):129-49. doi: 10.1111/j.1467-9558.2010.01370.x.

Coubes, Marie-Laure, Patricio Solis, and Maria Eugenia Zavala de Cosio. 2016. Generaciones, Cursos de Vida y Desigualdad Social En Mexico. First. Mexico: El Colegio de Mexico El Colegio de la Frontera Norte.

Crenshaw, Kimberle. 1991. "Mapping the Margins: Intersectionality, Identity Politics, and Violence against Women of Color." STANFORD LAW REVIEW 43:60.

Curran, Sara R., and Estela Rivero-Fuentes. 2003. "Engendering Migrant Networks: The Case of Mexican Migration.” Demography 40(2):289-307. doi: 10.1353/dem.2003.0011.

De Ferranti, David, Guillermo Perry, Francisco Ferreira, and Michael Walton. 2004. Inequality in Latin America : Breaking with History? Washington, DC: World Bank.

De Haas, Hein. 2014. "Migration Theory. Quo Vadis?” (DEMIG project paper 24).

Donato, Katharine M. 2010. “U.S. Migration from Latin America: Gendered Patterns and 
Shifts." The ANNALS of the American Academy of Political and Social Science 630(1):78-92. doi: 10.1177/0002716210368104.

Donato, Katharine M. 2016. Gender and International Migration: From the Slavery Era to the Global Age. 1st ed. New York: Russell Sage Foundation.

Donato, Katharine M., Jonathan Hiskey, Jorge Durand, and Douglas S. Massey. 2010. "Migration in the Americas: Mexico and Latin America in Comparative Context." The Annals of the American Academy of Political and Social Science 630(1):6-17. doi: $10.1177 / 0002716210368101$.

Esteve, Albert, and Ron J. Lesthaeghe. 2016. Cohabitation and Marriage in the Americas: Geo-Historical Legacies and New Trends. edited by A. Esteve and R. J. Lesthaeghe. Cham: Springer International Publishing.

Esteve, Albert, Ron Lesthaeghe, and Antonio López-Gay. 2012. "The Latin American Cohabitation Boom, 1970-2007." Population and Development Review 38(1):55-81. doi: 10.1111/j.1728-4457.2012.00472.x.

Frank, Reanne, and Patrick Heuveline. 2005. "A Crossover in Mexican and Mexican-American Fertility Rates: Evidence and Explanations for an Emerging Paradox." Demographic Research 12(4):77-104. doi: 10.4054/DemRes.2005.12.4.

Furstenberg, Fank. 2008. "The Intersections of Social Class and the Transition to Adulthood." New Directions for Child and Adolescent Development 119:1-10. doi: 10.1002/cd.

Fussell, Elizabeth. 2010. "The Cumulative Causation of International Migration in Latin America." The ANNALS of the American Academy of Political and Social Science 630(1):162-77. doi: 10.1177/0002716210368108.

Fussell, Elizabeth, and Alberto Palloni. 2004. "Persistent Marriage Regimes in Changing Times." Journal of Marriage and Family 66(5):1201-13.

García, Brígida, and Orlandina de Oliveira. 2011. "Family Changes and Public Policies in Latin America." Annual Review of Sociology 37(1):593-611. doi:

10.1146/annurev-soc-081309-150205.

Garip, Filiz. 2012. "Discovering Diverse Mechanisms of Migration: The Mexico-US Stream 1970-2000." Population and Development Review 38(3):393-433. doi: 10.1111/j.1728-4457.2012.00510.x.

Genz, Alan, and Frank Bretz. 2009. Computation of Multivariate Normal and t Probabilities. Vol. 195. Berlin, Heidelberg: Springer Berlin Heidelberg.

González-Ferrer, Amparo, Teresa Castro-Martín, Elisabeth Katharina Kraus, and Tatiana Eremenko. 2017. "Childbearing Patterns among Immigrant Women and Their Daughters in Spain: Over-Adaptation or Structural Constraints?" Demographic Research. doi: 10.4054/DemRes.2017.37.19.

González-Ferrer, Amparo, Ognjen Obućina, Clara Cortina, and Teresa Castro-Martín. 2018. "Mixed Marriages between Immigrants and Natives in Spain: The Gendered Effect of Marriage Market Constraints." Demographic Research 39(1):1-32. doi: 10.4054/DemRes.2018.39.1. 
Gower, J. C. 1971. “A General Coefficient of Similarity and Some of Its Properties.” Biometrics 27(4):857-71.

Guzmán, Jose. 1996. The Fertility Transition in Latin America. New York: Oxford Universit Press.

Guzmán, José, Jorge Rodríguez, Jorge Martínez, Juan Contreras, and Daniela González. 2006. "The Demography of Latin America and the Caribbean since 1950." Population English Edition 61(5-6):519-76. doi: 10.3917/pope.605.0519.

Hagan, Jacqueline Maria. 1998. "Social Networks, Gender and Immigrant Incorporation : Resources and Constraints." American Sociological Review 63(1):55-67.

Herrera, Gioconda. 2008. "Políticas Migratorias y Familias Transnacionales: Migración Ecuatoriana En España y Estados Unidos.” in América Latina migrante: Estado, familias, identidades, edited by G. Herrera and J. Ramirez. Quito: FLACSO - Ecuador.

Herrera, Gioconda. 2012. “Género y Migración Internacional En La Experiencia Latinoamericana. De La Visibilización Del Campo a Una Presencia Selectiva.” Política y Sociedad 49(1):35-46.

Herrera, Gioconda. 2013. "Gender and International Migration: Contributions and Cross-Fertilizations.” Annual Review of Sociology 39(1):471-89. doi: 10.1146/annurev-soc-071811-145446.

Hill Collins, Patricia, and Sirma Bilge. 2016. Intersectionality. Cambridge, UK ; Malden, MA: Polity Press.

Hondagneu-Sotelo, Pierrette. 1992. "Overcoming Patriarchal Constraints: The Reconstruction of Gender Relations Among Mexican Immigrant Women and Men.” Gender \& Society. doi: 10.1177/089124392006003004.

Hondagneu-Sotelo, Pierrette. 1994. Gendered Transitions. Mexican Experiences of Immigration. 1st ed. Berkeley: University of California Press.

Juarez, Fatima, and Cecilia Gayet. 2014. "Transitions to Adulthood in Developing Countries." Annual Review of Sociology 40:521-38. doi: 10.1146/annurev-soc-052914-085540.

Kanaiaupuni, Shawn Malia. 2000. "Reframing the Migration Question : An Analysis of Men, Women, and Gender in Mexico.” Social Forces 78(4):1311-47.

Kaufman, Leonard, and Peter J. Rousseeuw. 1990. Finding Groups in Data: An Introduction to Cluster Analysis. New York: Wiley.

Kleinepier, Tom, Helga A. G. de Valk, and Ruben van Gaalen. 2015. "Life Paths of Migrants: A Sequence Analysis of Polish Migrants' Family Life Trajectories.” European Journal of Population 31(2):155-79. doi: 10.1007/s10680-015-9345-1.

Kraus, Elisabeth Katharina. 2019. "Family Formation Trajectories across Borders: A Sequence Analysis Approach to Senegalese Migrants in Europe." Advances in Life Course Research 42:100290. doi: 10.1016/j.alcr.2019.100290.

Kulu, Hill. 2005. "Migration and Fertility: Competing Hypotheses Re-Examined." European Journal of Population 21(1):51-87. doi: 10.1007/s10680-005-3581-8.

Kulu, Hill, and Amparo González-Ferrer. 2014. "Family Dynamics Among Immigrants and 
Their Descendants in Europe: Current Research and Opportunities." European Journal of Population 30(4):411-35. doi: 10.1007/s10680-014-9322-0.

Landale, N., and R. Oropesa. 2007. "Hispanic Familie: Stability and Change." Annual Review of Sociology 33. doi: 10.1146/annurev.soc.33.040406.131655.

Lesnard, Laurent. 2010. Setting Cost in Optimal Matching to Uncover Contemporaneous Socio-Temporal Patterns. Vol. 38.

Lima, Everton E. C., Krystof Zeman, Tomas Sobotka, Mathias Nathan, and Ruben Castro. 2018. "The Emergence of Bimodal Fertility Profiles in Latin America." Population and Development Review 0(0):1-21. doi: 10.1111/padr.12157.

Lindstrom, David P., and Silvia Giorguli-Saucedo. 2007. "The Interrelationship of Fertility, Family Maintenance and Mexico-U.S. Migration.” Demographic Research 17:821-58. doi: 10.4054/DemRes.2007.17.28.

Lindstrom, David P., Anairis Hernandez-Jabalera, and Silvia Giorguli Saucedo. 2021. "Migration, Family Formation and Fertility in the Americas." International Migration Review 55(1):280-314. doi: 10.1177/0197918320923353.

Massey, Douglas. 1990. "Social Structure, Household Strategies, and the Cumulative Causation of Migration." Population Index 56(1):3-26.

Massey, Douglas, and Fernando Riosmena. 2010. "Undocumented Migration from Latin America in an Era of Rising U.S. Enforcement." The Annals of the American Academy of Political and Social Science 630(1):294-321. doi: 10.1177/0002716210368114.

Massey, Douglas S., and Chiara Capoferro. 2006. "Salvese Quien Pueda: Structural Adjustment and Emigration from Lima." The ANNALS of the American Academy of Political and Social Science 606(1):116-27. doi: 10.1177/0002716206288105.

Massey, Douglas S., Jorge Durand, and Karen A. Pren. 2014. "Explaining Undocumented Migration to the U.S." International Migration Review 48(4):1028-61. doi: 10.1111/imre.12151.

Massey, Douglas S., Mary J. Fischer, and Chiara Capoferro. 2006. "International Migration and Gender in Latin America: A Comparative Analysis." International Migration 44(5):63-91. doi: 10.1111/j.1468-2435.2006.00387.x.

Massey, Douglas, and Rene Zenteno. 2000. "A Validation of the Ethnosurvey: The Case of Mexico-US Migration." International Migration Review 34(3):766-93. doi: $10.2307 / 2675944$.

McLanahan, Sara, and Christine Percheski. 2008. "Family Structure and the Reproduction of Inequalities." Annual Review of Sociology 34(1):257-76.

Organization of American States. 2011. International Migration in the Americas: First Report of the Continuous Reporting System of International Migration in the Americas 2011. Washington, D.C.: Migration and Development Program.

Parrado, Emilio A. 2011. "How High Is Hispanic/Mexican Fertility in the United States? Immigration and Tempo Considerations." Demography 48(3):395-409. doi: 10.1007/s.

Parrado, Emilio A., and Chenoa A. Flippen. 2005. "Migration and Gender among Mexican 
Women." American Sociological Review 70(4):606-32. doi:

10.1177/000312240507000404.

Parrado, Emilio A., and S. Phillip Morgan. 2008. "Intergenerational Fertility among Hispanic Women: New Evidence of Immigrant Assimilation.” Demography 45(3):651-71.

Pedraza, Silvia. 1991. "WOMEN AND MIGRATION: The Social Consequences of Gender." Annual Review of Sociology 17:303-25.

Pikkety, Thomas. 2019. Capital et Idéologie. 1st ed. Paris: Seuil.

Portes, Alejandro. 2010. "Migration and Social Change: Some Conceptual Reflections." Journal of Ethnic and Migration Studies 36(10):1537-63. doi: 10.1080/1369183X.2010.489370.

Portes, Alejandro, and Kelly Hoffman. 2003. "Latin American Class Structures: Their Composition and Change during the Neoliberal Era." Latin American Research Review 38(1):41-82. doi: 10.1353/lar.2003.0011.

Quilodrán, Julieta. 2011. ¿¿Un Modelo de Nupcialidad Postransicional En América Latina?” Pp. 11-34 in III Congreso de la Asociación Latinoamericana de Población. Cordoba, Argentina.

Riosmena, Fernando. 2016. "The Potential and Limitations of Cross-Context Comparative Research on Migration." The Annals of the American Academy of Political and Social Science 666(1):28-45. doi: 10.1177/0002716216650629.

Rodríguez Vignoli, Jorge, and Gustavo Busso. 2009. Migración Interna y Desarrollo En América Latina Entre 1980 y 2005. 1st ed. Santiago de Chile: Comisión Económica para América Latina y el Caribe.

Sana, Mariano, and Douglas Massey. 2005. "Household Composition, Family Migration, and Community Context: Migration Remittances in Four Countries." Social Science Quarterly 86(2):509-28.

Sassen-Koob, Saskia. 1984. "Notes on the Incorporation of Third World Women into Wage-Labor Through Immigration and Off-Shore Production." The International Migration Review 18(4):1144-67.

Stephen, Elizabeth Hervey, and Frank D. Bean. 1992. "Assimilation, Disruption and the Fertility of Mexican-Origin Women in the United States." International Migration Review 26(1):67-88. doi: 10.2307/2546937.

Studer, Matthias. 2013. "WeightedCluster Library Manual: A Practical Guide to Creating Typologies of Trajectories in the Social Sciences with R." LIVES Working Papers, 24. doi: http://dx.doi.org/10.12682/lives.2296-1658.

Urdinola, B. Piedad, and Carlos Ospino. 2015. "Long-Term Consequences of Adolescent Fertility: The Colombian Case.” Demographic Research 32(1):1487-1518. doi: 10.4054/DemRes.2015.32.55.

Urdinola, B. Piedad, and Jorge A. Tovar. 2017. Time Use and Gender in Colombia. Berkeley, CA: NTA Working Paper 17-06.

Van Hear, Nicholas. 2014. "Reconsidering Migration and Class." International Migration Review 48(1_suppl):100-121. doi: 10.1111/imre.12139. 
Table 1: Analytical sample by sex, type of migration, and age at migration.

\begin{tabular}{lrrr}
\hline \multirow{2}{*}{ Age at migration } & \multicolumn{2}{c}{ Sex } & \multirow{2}{*}{ Total } \\
\cline { 2 - 3 } & Women & Men & \\
\hline Non-migrant & 5,265 & 3,708 & 8,973 \\
Inte rnal & & & \\
$\quad$ Before 18 & 1,051 & 966 & 2,017 \\
19 to 24 & 579 & 649 & 1,228 \\
25 to 30 & 292 & 341 & 633 \\
After 30 & 266 & 390 & 656 \\
Sub-total & 2,188 & 2,346 & 4,534 \\
\hline International & & & \\
Before 18 & 98 & 390 & 488 \\
19 to 24 & 152 & 618 & 770 \\
25 to 30 & 149 & 468 & 617 \\
After 30 & 199 & 632 & 831 \\
Sub-total & 598 & 2,108 & 2,706 \\
\hline Total & 8,051 & 8,162 & 16,213 \\
\hline Birth cohort and household headship & & \\
\% born between 1950 and 1969 & 80.1 & 71.5 & 75.8 \\
\% head of household & 19.0 & 98.2 & 58.8 \\
\hline
\end{tabular}

Note: The analytical sample includes household heads and partners that were born between 1940 and 1977 (i.e., aged 39 to 50 at the time of survey) in eight Latin American and Caribbean countries covered by the Mexican and Latin American Migration projects. 
Figure 1: Time trends in emigration rates and emigration sex ratios to the United States, Spain, and Canada from eight Latin American and Caribbean countries in the natural logarithm scale.
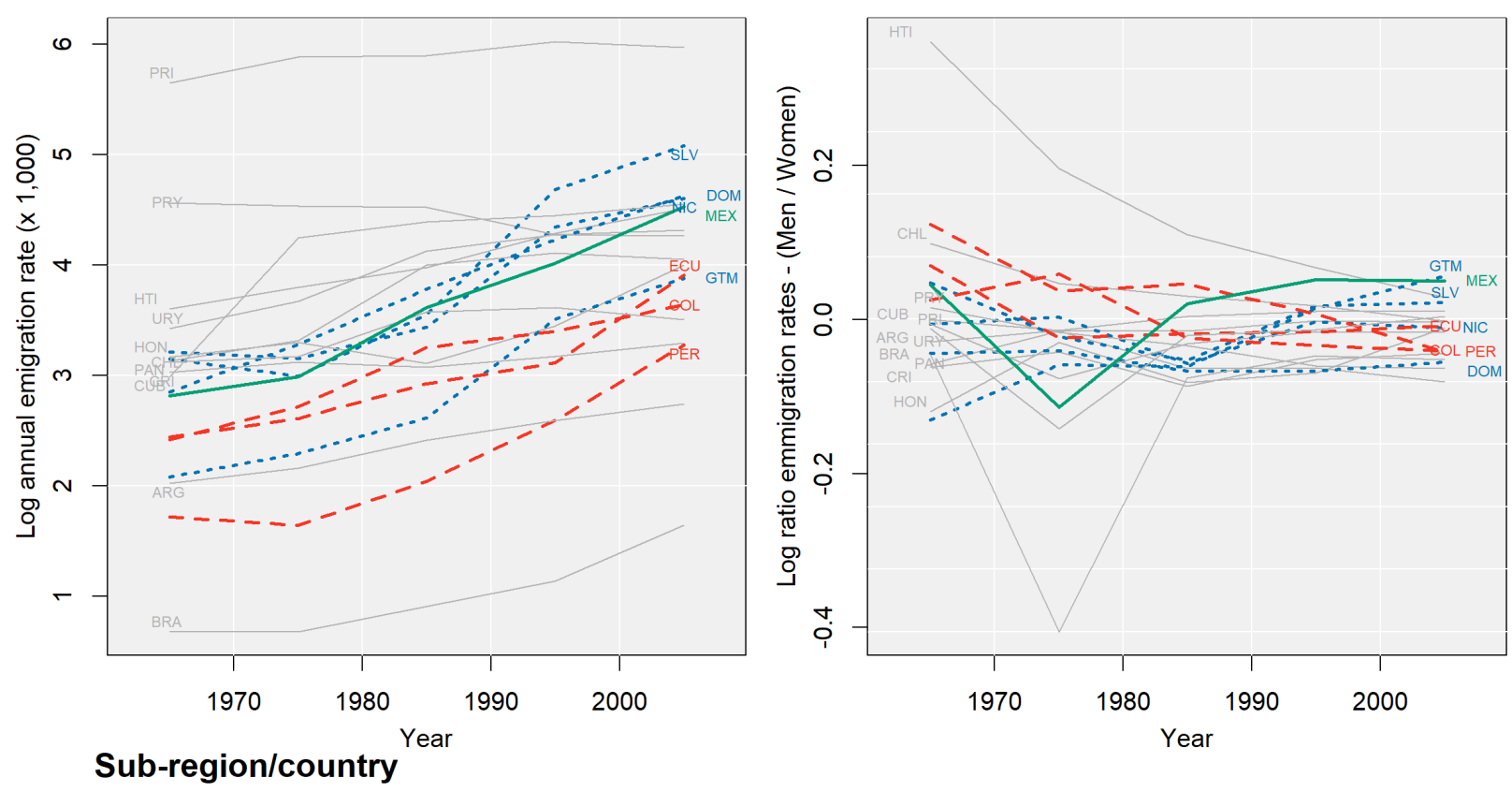

Not included _- - South American ….

Note: Migration data come from the World Bank - Global Migration Database. Population data come from the United Nations Population Prospects (2017). Countries are labeled as Argentina (ARG), Brazil (BRA), Chile (CHL), Colombia (COL), Costa Rica (CRI), Cuba (CUB), Dominican Republic (DOM), Ecuador (ECU), El Salvador (SLV), Guatemala (GTM), Haiti (HTI), Honduras (HND), Mexico (MEX), Nicaragua (NIC), Panama (PAN), Paraguay (PRY), Peru (PER), Puerto Rico (PRI), Uruguay (URY). 
Table 2: Migration prevalence and educational attainment by sex and type of migration - bolded values indicate statistically significant differences compared to Non-migrant.

\begin{tabular}{|c|c|c|c|c|c|c|c|c|c|c|c|c|}
\hline \multirow{2}{*}{$\begin{array}{c}\text { Migration } \\
\text { status }\end{array}$} & \multirow{2}{*}{$\begin{array}{c}\text { Women } \\
\%\end{array}$} & \multicolumn{4}{|c|}{ Educational attainment } & \multirow{2}{*}{ Total } & \multirow{2}{*}{$\begin{array}{c}\text { Men } \\
\%\end{array}$} & \multicolumn{4}{|c|}{ Educational attainment } & \multirow{2}{*}{ Total } \\
\hline & & Lowest & Low & Med. & High & & & Lowest & Low & Med. & High & \\
\hline Non-migrant & $\begin{array}{l}60.7 \\
(1.8)\end{array}$ & $\begin{array}{l}59.5 \\
(2.2)\end{array}$ & $\begin{array}{l}18.3 \\
(1.3)\end{array}$ & $\begin{array}{l}12.5 \\
(0.9)\end{array}$ & $\begin{array}{r}9.7 \\
(1.2)\end{array}$ & 100 & $\begin{array}{l}41.2 \\
(2.1)\end{array}$ & $\begin{array}{l}54.0 \\
(2.3)\end{array}$ & $\begin{array}{l}17.0 \\
(1.4)\end{array}$ & $\begin{array}{l}14.1 \\
(1.1)\end{array}$ & $\begin{array}{l}14.9 \\
(1.5)\end{array}$ & 100 \\
\hline Dom. migrant & $\begin{array}{l}27.2 \\
(1.6)\end{array}$ & $\begin{array}{l}56.2 \\
(2.6)\end{array}$ & $\begin{array}{r}\mathbf{1 1 . 0} \\
(0.9)\end{array}$ & $\begin{array}{r}\mathbf{1 5 . 5} \\
(1.3)\end{array}$ & $\begin{array}{r}17.3 \\
(1.9)\end{array}$ & 100 & $\begin{array}{l}27.6 \\
(1.4)\end{array}$ & $\begin{array}{l}51.0 \\
(2.7)\end{array}$ & $\begin{array}{r}12.9 \\
(1.1)\end{array}$ & $\begin{array}{l}12.6 \\
(1.0)\end{array}$ & $\begin{array}{r}23.5 \\
(2.1)\end{array}$ & 100 \\
\hline Intl. migrant & $\begin{array}{l}12.1 \\
(1.3)\end{array}$ & $\begin{array}{r}44.7 \\
(4.5)\end{array}$ & $\begin{array}{l}15.6 \\
(2.8)\end{array}$ & $\begin{array}{r}19.4 \\
(2.7)\end{array}$ & $\begin{array}{r}20.3 \\
(3.3)\end{array}$ & 100 & $\begin{array}{l}31.3 \\
(2.0)\end{array}$ & $\begin{array}{r}59.3 \\
(3.1)\end{array}$ & $\begin{array}{l}16.9 \\
(1.6)\end{array}$ & $\begin{array}{l}11.3 \\
(1.8)\end{array}$ & $\begin{array}{l}12.5 \\
(1.7)\end{array}$ & 100 \\
\hline Total & 100 & & & & & & 100 & & & & & \\
\hline
\end{tabular}

Note: Educational attainment categories are based on completed years of schooling: 0-4 (Lowest), 5-8 (Low), 9-12 (Med.), and 13+ (High). Standard errors, in parentheses, are clustered at the community level. 
Figure 2: Individual family trajectories and family typology by sex and percentages by region.
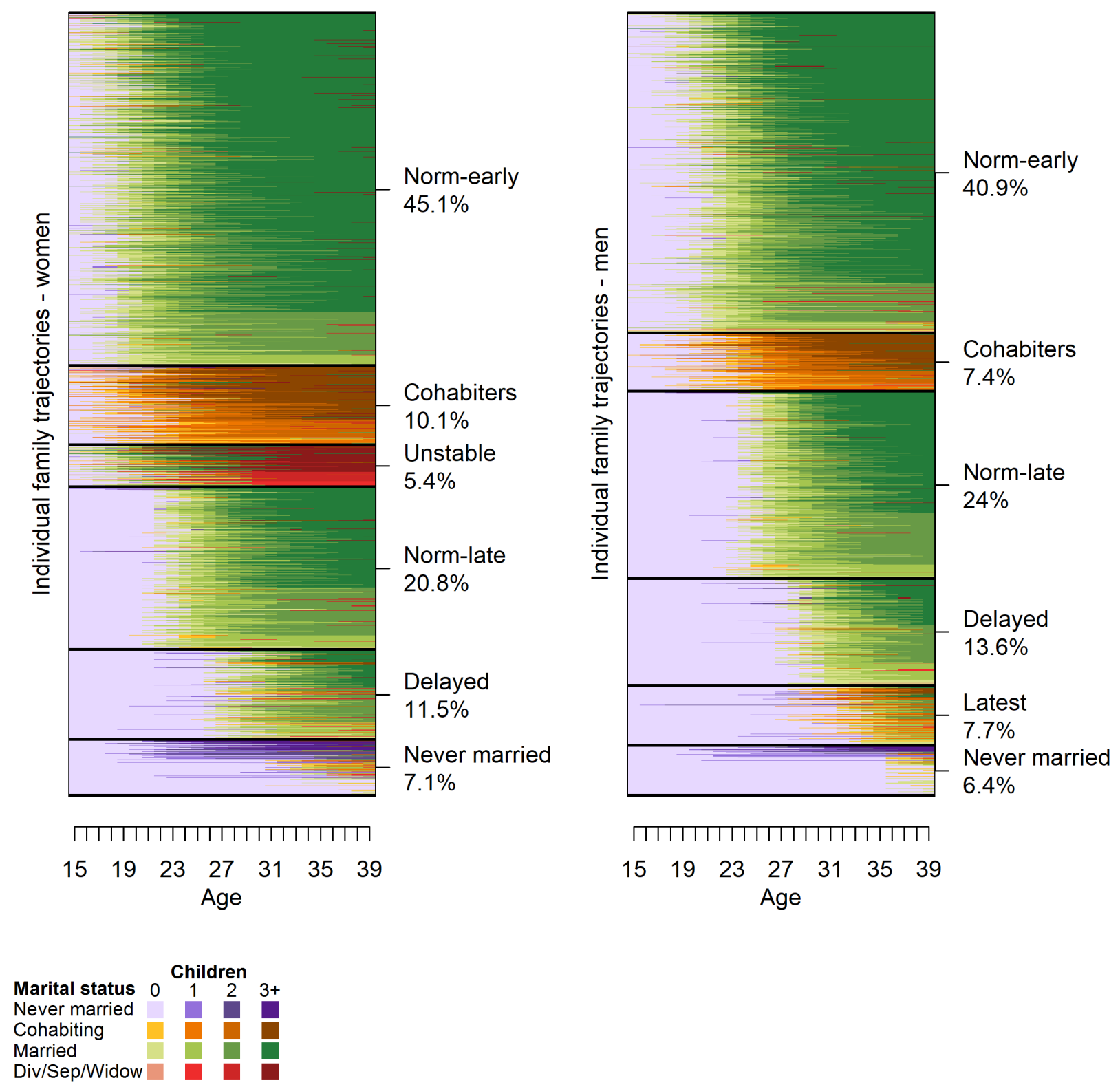

Note: Individual trajectories are sorted by completed fertility within each family category. Even though figures account for sample weights, interpretations should be cautious due to overplotting. 
Table 3: Comparison of family typologies for all individuals and household heads and proportion of household heads in each family category by sex.

\begin{tabular}{|c|c|c|c|c|c|c|c|c|c|}
\hline & \multicolumn{6}{|c|}{ Family trajectory types among household heads } & \multirow{2}{*}{$\begin{array}{l}\text { Spouse/ } \\
\text { partner }\end{array}$} & \multirow{2}{*}{ Total } & \multirow{2}{*}{$\begin{array}{c}\% \text { h. } \\
\text { heads }\end{array}$} \\
\hline & ft-01 & $\mathrm{ft}-02$ & $\mathrm{ft}-03$ & $\mathrm{ft}-04$ & $\mathrm{ft}-05$ & $\mathrm{ft}-06$ & & & \\
\hline \multicolumn{10}{|l|}{ Women } \\
\hline Never married & 266 & 1 & - & - & - & - & 265 & 532 & 50.2 \\
\hline Delayed & - & 134 & 15 & - & - & - & 786 & 935 & 15.9 \\
\hline Norm-late & - & 21 & 8 & - & - & 131 & 1,399 & 1,559 & 10.3 \\
\hline Unstable & - & - & 99 & 265 & - & - & 40 & 404 & 90.1 \\
\hline Cohabiters & - & - & 30 & - & 200 & 1 & 682 & 913 & 25.3 \\
\hline Norm-early & - & - & - & 3 & - & 352 & 3,353 & 3,708 & 9.6 \\
\hline Total & 266 & 156 & 152 & 268 & 200 & 484 & 6,525 & 8,051 & 19.0 \\
\hline \multicolumn{10}{|l|}{ Men } \\
\hline Never married & 413 & 41 & - & - & - & - & 11 & 465 & 97.6 \\
\hline Latest & 10 & 497 & 129 & - & 28 & - & 25 & 689 & 96.4 \\
\hline Delayed & - & 87 & 899 & - & 2 & - & 16 & 1,004 & 98.4 \\
\hline Norm-late & - & - & 211 & 1,631 & 8 & - & 24 & 1,874 & 98.7 \\
\hline Cohabiters & - & - & - & - & 678 & 8 & 33 & 719 & 95.4 \\
\hline Norm-early & - & - & - & 557 & 4 & 2,810 & 40 & 3,411 & 98.8 \\
\hline Total & 423 & 625 & 1,239 & 2,188 & 720 & 2,818 & 149 & 8,162 & 98.2 \\
\hline
\end{tabular}

Note: The family trajectory types for household heads are sorted by average completed fertility from lowest (ft-01) to highest (ft-06). A visualization of the ft-typology is included in the appendix, Figure A3. 
Table 4: Marginal distribution of the family typology by regions for women (top) and men (bottom).

\begin{tabular}{|c|c|c|c|c|c|c|c|}
\hline \multirow[b]{2}{*}{ Region } & \multicolumn{6}{|c|}{ Family typology - women $(\%)$} & \multirow[b]{2}{*}{ Total } \\
\hline & $\begin{array}{c}\text { Never } \\
\text { married }\end{array}$ & Delayed & Norm-late & Unstable & Cohabiters & $\begin{array}{c}\text { Norm- } \\
\text { early }\end{array}$ & \\
\hline \multirow[t]{2}{*}{ Mexico } & 6.3 & 10.7 & 21.2 & 4.6 & 6.8 & 50.4 & 100 \\
\hline & $(0.6)$ & $(0.5)$ & $(0.9)$ & $(0.5)$ & $(0.9)$ & $(1.1)$ & \\
\hline \multirow[t]{2}{*}{ Central America } & 6.2 & 12.9 & 18.5 & 8.2 & 23.6 & 30.6 & 100 \\
\hline & $(1.2)$ & (1.1) & (1.7) & (1.3) & $(2.1)$ & $(2.4)$ & \\
\hline \multirow[t]{2}{*}{ South America } & 12.0 & 14.1 & 20.5 & 6.6 & 14.9 & 31.9 & 100 \\
\hline & $(1.6)$ & $(1.2)$ & $(2.0)$ & $(1.1)$ & $(1.9)$ & $(2.7)$ & \\
\hline \multirow[b]{2}{*}{ Region } & \multicolumn{6}{|c|}{ Family typology - men (\%) } & \\
\hline & $\begin{array}{c}\text { Never } \\
\text { married }\end{array}$ & Latest & Delayed & Norm-late & Cohabiters & $\begin{array}{c}\text { Norm- } \\
\text { early }\end{array}$ & Total \\
\hline \multirow[t]{2}{*}{ Mexico } & 5.6 & 6.4 & 13.3 & 24.5 & 5.2 & 45.0 & 100 \\
\hline & $(0.5)$ & $(0.5)$ & $(1.0)$ & (1.1) & $(0.6)$ & $(1.2)$ & \\
\hline \multirow[t]{2}{*}{ Central America } & 8.3 & 12.4 & 12.4 & 20.3 & 18.5 & 28.1 & 100 \\
\hline & $(1.8)$ & (1.2) & $(1.4)$ & (1.1) & $(2.3)$ & $(2.1)$ & \\
\hline \multirow[t]{2}{*}{ South America } & 10.3 & 12.1 & 16.4 & 23.7 & 12.8 & 24.7 & 100 \\
\hline & $(2.0)$ & $(1.5)$ & (3.3) & $(2.1)$ & $(1.9)$ & $(2.6)$ & \\
\hline
\end{tabular}

Note: Standard errors, in parentheses, are clustered at the community level. 
Figure 3: Family profiles' factorial coordinates by type of migration, age at migration, and educational attainment for women.

Internal migration

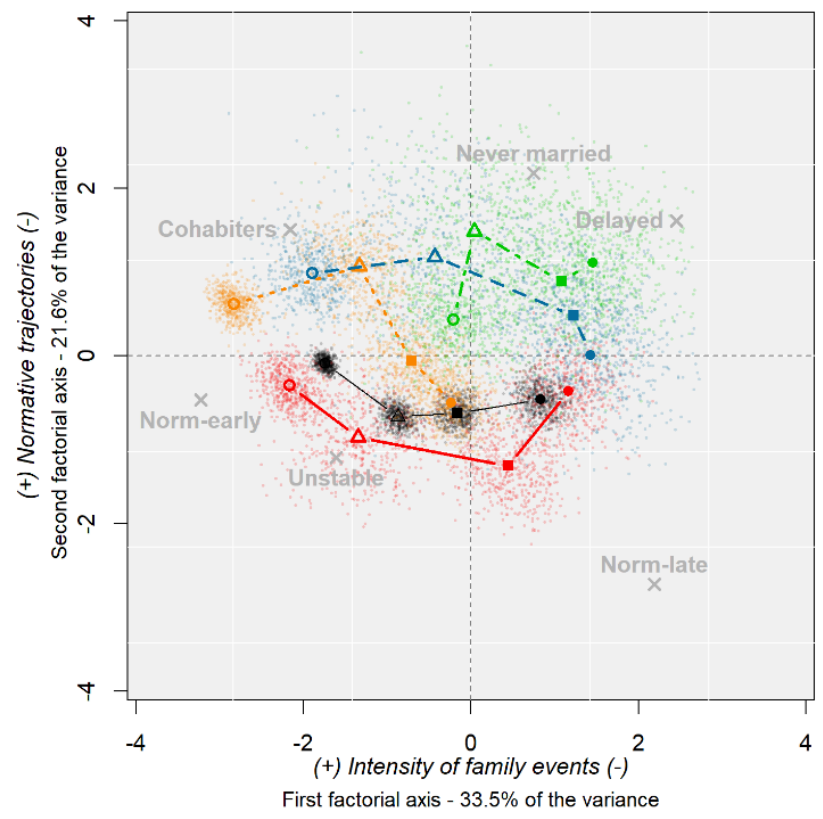

Years of schooling

$\circ$ 0-4 $\triangle 5-8 \quad 9-12 \cdot 13+$

Age at migration

\section{International migration}

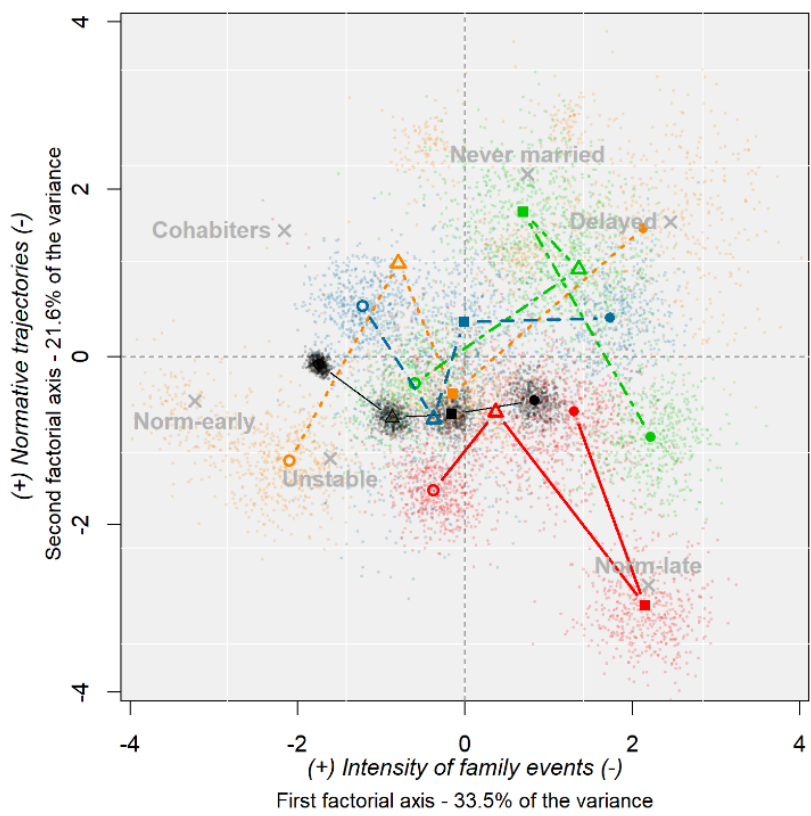

First factorial axis $-33.5 \%$ of the variance

$--25-30 \quad--$ After age 30

Note: The mean family profile is Never married (10.7\%), Delayed (18.2\%), Norm-late (23.8\%), Unstable (5.8\%), Cohabiters (7.2\%), and Norm-early (34.2\%). White background lines are separated by one standard deviation of the factorial coordinates. 
Figure 4: Family profiles' factorial coordinates by type of migration, age at migration, and educational attainment for men.

Internal migration

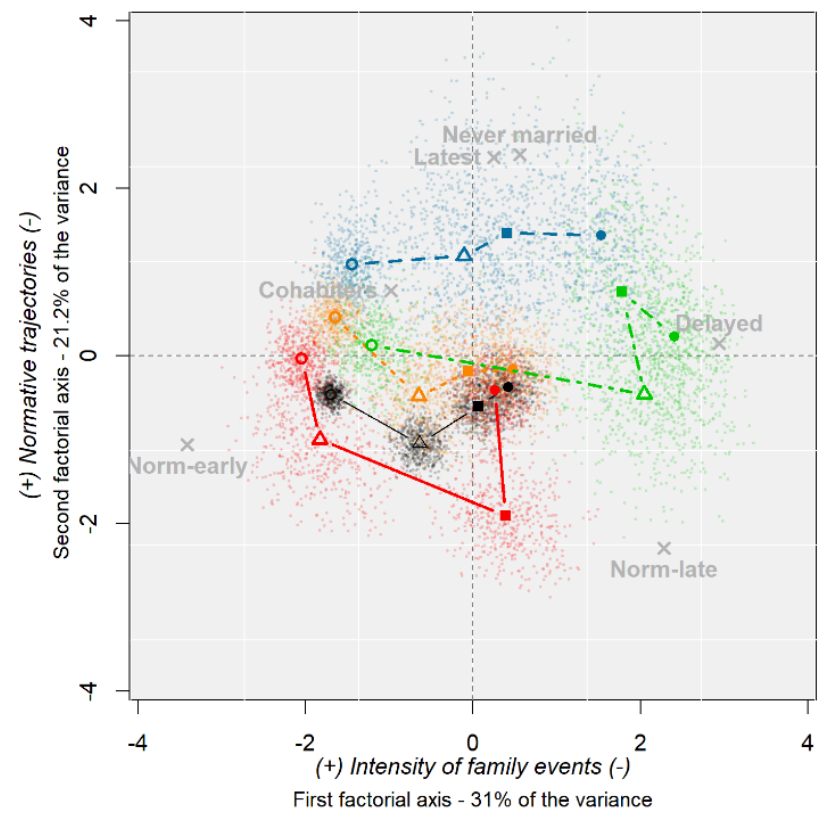

Years of schooling

$\circ$ 0-4 $\triangle 5-8 \quad 9-12 \cdot 13+$

Age at migration
International migration

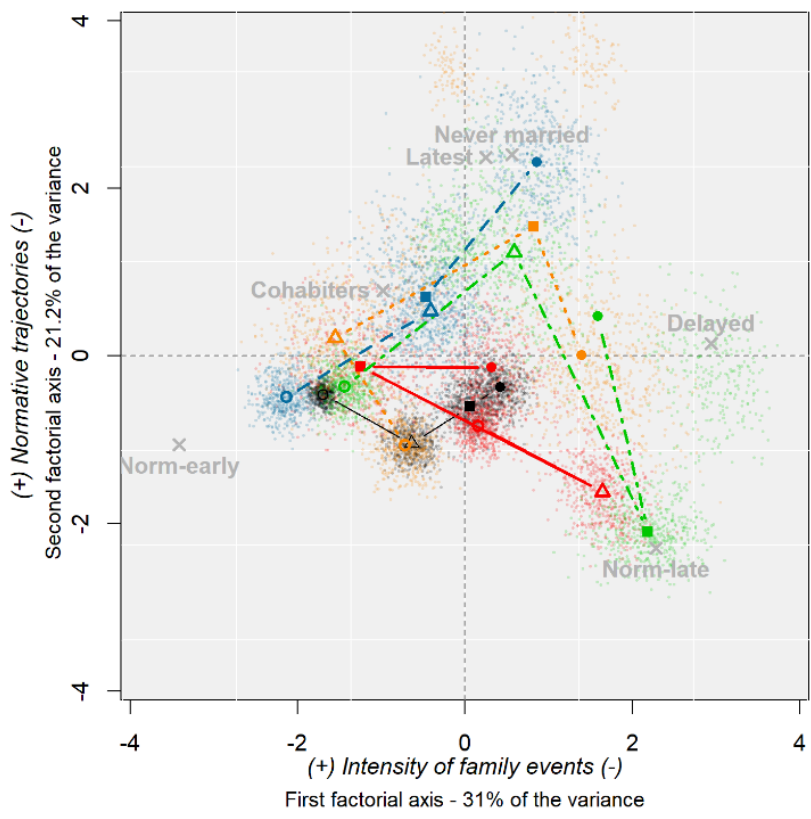

$--25-30 \quad--$ After age 30

Note: The mean family profile is Never married (8.4\%), Latest (8.9\%), Delayed (16.9\%), Norm-late (25.8\%), Cohabiters (6.5\%), and Norm-early (33.5\%). White background lines are separated by one standard deviation of the factorial coordinates. 
Appendix 
Figure A1: Individual international migration trajectories according to time spent abroad and age at first domestic migration.
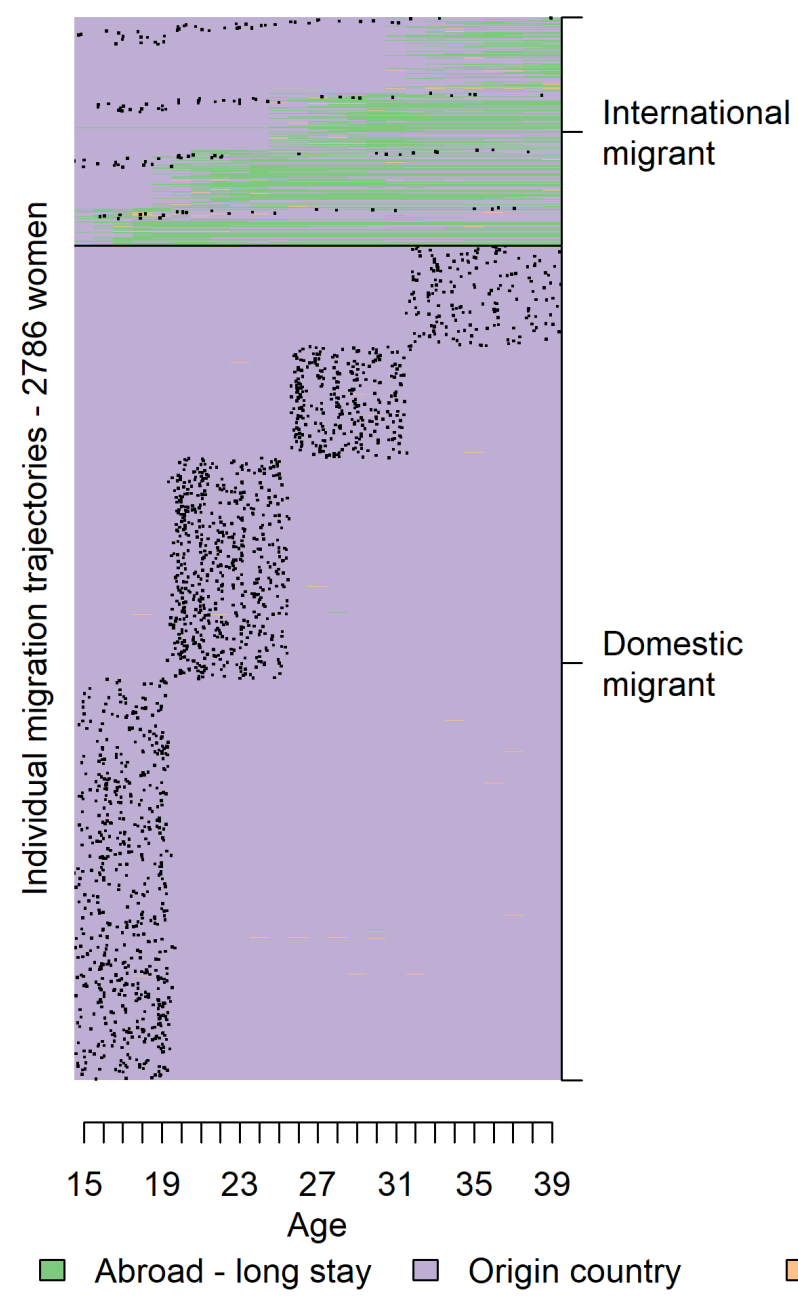

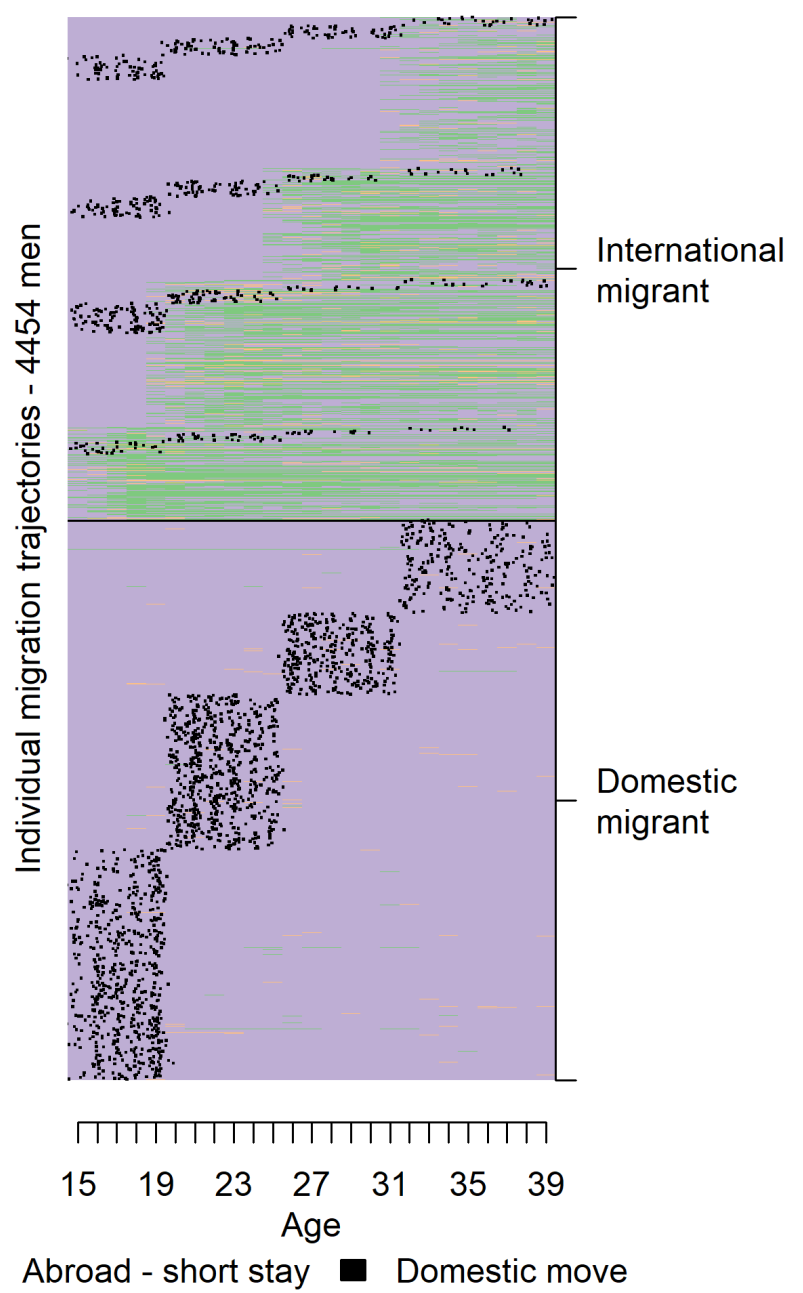

Note: The individual sequences are sorted by type (domestic and international) and age at migration groups $(<18,19-24,25-30,+30)$. We add $\alpha$ years to the age at migration to favor visualization, where $\alpha$ is normally distributed with a mean of 0.5 and a standard deviation of 0.15. Long stays correspond to six or more months. The plot is not weighted, and interpretation should be cautious due to overplotting. 
Table A1: Analytical sample by sex, birth cohort groups, three types of migration, and age at migration groups.

\begin{tabular}{|c|c|c|c|c|c|c|c|c|c|c|}
\hline \multirow{2}{*}{$\begin{array}{l}\text { Age and type } \\
\text { of migration }\end{array}$} & \multicolumn{4}{|c|}{$\begin{array}{c}\text { Women } \\
\text { Birth cohort }\end{array}$} & \multicolumn{6}{|c|}{ Men } \\
\hline & $1940-49$ & $1950-59$ & $1960-69$ & $>1970$ & Total & $1940-49$ & $1950-59$ & $1960-69$ & $>1970$ & Total \\
\hline Non-migrant & 426 & 1,976 & 2,115 & 680 & 5,197 & 430 & 1,200 & 1,421 & 427 & 3,478 \\
\hline \multicolumn{11}{|l|}{ Internal } \\
\hline Before 18 & 60 & 487 & 402 & 85 & 1,034 & 119 & 420 & 288 & 63 & 890 \\
\hline 19 to 24 & 36 & 242 & 238 & 54 & 570 & 123 & 249 & 182 & 37 & 591 \\
\hline 25 to 30 & 21 & 113 & 113 & 40 & 287 & 59 & 132 & 88 & 29 & 308 \\
\hline After 30 & 18 & 128 & 99 & 21 & 266 & 87 & 148 & 93 & 24 & 352 \\
\hline Sub-total & 135 & 970 & 852 & 200 & 2,157 & 388 & 949 & 651 & 153 & 2,141 \\
\hline \multicolumn{11}{|l|}{ International } \\
\hline Before 18 & 7 & 36 & 18 & 18 & 79 & 31 & 101 & 101 & 66 & 299 \\
\hline 19 to 24 & 6 & 53 & 37 & 16 & 112 & 98 & 154 & 131 & 67 & 450 \\
\hline 25 to 30 & 3 & 32 & 41 & 26 & 102 & 71 & 93 & 96 & 50 & 310 \\
\hline After 30 & 25 & 70 & 60 & 16 & 171 & 100 & 159 & 174 & 41 & 474 \\
\hline Sub-total & 41 & 191 & 156 & 76 & 464 & 300 & 507 & 502 & 224 & 1,533 \\
\hline \multicolumn{11}{|c|}{ Internal and international } \\
\hline Before 18 & 11 & 59 & 35 & 12 & 117 & 128 & 191 & 100 & 25 & 444 \\
\hline 19 to 24 & 5 & 27 & 21 & 6 & 59 & 94 & 120 & 49 & 13 & 276 \\
\hline 25 to 30 & 2 & 9 & 13 & 4 & 28 & 59 & 50 & 28 & 4 & 141 \\
\hline After 30 & 3 & 7 & 14 & 5 & 29 & 64 & 48 & 22 & 15 & 149 \\
\hline Sub-total & 21 & 102 & 83 & 27 & 233 & 345 & 409 & 199 & 57 & 1,010 \\
\hline Total & 623 & 3,239 & 3,206 & 983 & 8,051 & 1,463 & 3,065 & 2,773 & 861 & 8,162 \\
\hline
\end{tabular}

Note: The analytical sample includes household heads and partners that were born between 1940 and 1977 (i.e., aged 39 to 50 at the time of survey) in eight Latin American and Caribbean countries covered by the Mexican and Latin American Migration projects. 
Table A2: Migration prevalence and educational attainment by sex, type of migration, and age at migration.

\begin{tabular}{|c|c|c|c|c|c|c|c|c|c|c|c|c|}
\hline \multirow{2}{*}{$\begin{array}{c}\text { Age at } \\
\text { migration }\end{array}$} & \multirow{2}{*}{ Women } & \multicolumn{4}{|c|}{ Educational attainment } & \multirow[b]{2}{*}{ Total } & \multirow{2}{*}{ Men } & \multicolumn{4}{|c|}{ Educational attainment } & \multirow[b]{2}{*}{ Total } \\
\hline & & Lowest & Low & Med. & High & & & Lowest & Low & Med. & High & \\
\hline Non-migrant & $\begin{array}{r}60.7 \\
(1.8)\end{array}$ & $\begin{array}{l}59.4 \\
(2.2)\end{array}$ & $\begin{array}{l}18.3 \\
(1.3)\end{array}$ & $\begin{array}{l}12.5 \\
(1.0)\end{array}$ & $\begin{array}{r}9.8 \\
(1.3)\end{array}$ & 100 & $\begin{array}{r}41.2 \\
(2.1)\end{array}$ & $\begin{array}{l}53.8 \\
(2.3)\end{array}$ & $\begin{array}{l}17.0 \\
(1.4)\end{array}$ & $\begin{array}{l}14.2 \\
(1.2)\end{array}$ & $\begin{array}{l}15.0 \\
(1.5)\end{array}$ & 100 \\
\hline \multicolumn{13}{|c|}{ Upper panel: Internal migrants by age at migration } \\
\hline$<18$ & $\begin{array}{l}13.0 \\
(1.1)\end{array}$ & $\begin{array}{r}58.4 \\
(3.0)\end{array}$ & $\begin{array}{l}10.9 \\
(1.3)\end{array}$ & $\begin{array}{l}13.8 \\
(1.5)\end{array}$ & $\begin{array}{r}16.9 \\
(2.1)\end{array}$ & 100 & $\begin{array}{r}10.9 \\
(0.8)\end{array}$ & $\begin{array}{r}50.6 \\
(2.9)\end{array}$ & $\begin{array}{r}14.5 \\
(1.6)\end{array}$ & $\begin{array}{l}13.4 \\
(1.6)\end{array}$ & $\begin{array}{r}21.6 \\
(2.6)\end{array}$ & 100 \\
\hline 19 to 24 & $\begin{array}{r}7.3 \\
(0.5)\end{array}$ & $\begin{array}{l}50.7 \\
(3.8)\end{array}$ & $\begin{array}{l}11.4 \\
(1.5)\end{array}$ & $\begin{array}{l}17.6 \\
(2.3)\end{array}$ & $\begin{array}{r}20.3 \\
(2.5)\end{array}$ & 100 & $\begin{array}{r}7.8 \\
(0.6)\end{array}$ & $\begin{array}{l}45.7 \\
(3.6)\end{array}$ & $\begin{array}{r}9.4 \\
(1.5)\end{array}$ & $\begin{array}{l}13.3 \\
(1.9)\end{array}$ & $\begin{array}{r}31.6 \\
(3.4)\end{array}$ & 100 \\
\hline 25 to 30 & $\begin{array}{r}3.3 \\
(0.3)\end{array}$ & $\begin{array}{l}57.2 \\
(3.8)\end{array}$ & $\begin{array}{l}11.2 \\
(1.9)\end{array}$ & $\begin{array}{l}16.4 \\
(2.6)\end{array}$ & $\begin{array}{l}15.2 \\
(2.4)\end{array}$ & 100 & $\begin{array}{r}3.9 \\
(0.3)\end{array}$ & $\begin{array}{l}52.3 \\
(4.6)\end{array}$ & $\begin{array}{l}14.0 \\
(2.4)\end{array}$ & $\begin{array}{l}12.9 \\
(2.4)\end{array}$ & $\begin{array}{l}20.8 \\
(2.9)\end{array}$ & 100 \\
\hline$>30$ & $\begin{array}{r}3.6 \\
(0.4)\end{array}$ & $\begin{array}{r}57.6 \\
(4.6)\end{array}$ & $\begin{array}{l}10.3 \\
(2.4)\end{array}$ & $\begin{array}{l}17.1 \\
(2.9)\end{array}$ & $\begin{array}{l}15.0 \\
\text { (3.0) }\end{array}$ & 100 & $\begin{array}{r}5.0 \\
(0.5)\end{array}$ & $\begin{array}{r}58.7 \\
\text { (3.4) }\end{array}$ & $\begin{array}{l}14.0 \\
(2.1)\end{array}$ & $\begin{array}{r}9.9 \\
(1.5)\end{array}$ & $\begin{array}{l}17.4 \\
\text { (3.0) }\end{array}$ & 100 \\
\hline \multicolumn{13}{|c|}{ Lower panel: International migrants by age at migration } \\
\hline$<18$ & $\begin{array}{r}2.2 \\
(0.4)\end{array}$ & $\begin{array}{r}41.3 \\
(10.3)\end{array}$ & $\begin{array}{r}23.2 \\
(6.4)\end{array}$ & $\begin{array}{r}27.9 \\
(7.8)\end{array}$ & $\begin{array}{r}7.5 \\
(4.8)\end{array}$ & 100 & $\begin{array}{r}5.8 \\
(0.8)\end{array}$ & $\begin{array}{r}58.3 \\
(5.3)\end{array}$ & $\begin{array}{l}18.3 \\
(3.7)\end{array}$ & $\begin{array}{l}11.0 \\
(3.1)\end{array}$ & $\begin{array}{r}12.4 \\
(2.8)\end{array}$ & 100 \\
\hline 19 to 24 & $\begin{array}{r}3.8 \\
(0.8)\end{array}$ & $\begin{array}{l}47.3 \\
(8.0)\end{array}$ & $\begin{array}{r}14.0 \\
(3.8)\end{array}$ & $\begin{array}{r}17.8 \\
(7.3)\end{array}$ & $\begin{array}{r}20.8 \\
(5.8)\end{array}$ & 100 & $\begin{array}{r}10.4 \\
(1.2)\end{array}$ & $\begin{array}{l}61.8 \\
(3.8)\end{array}$ & $\begin{array}{r}17.9 \\
(2.6)\end{array}$ & $\begin{array}{c}8.7 \\
(2.0)\end{array}$ & $\begin{array}{r}11.6 \\
(2.2)\end{array}$ & 100 \\
\hline 25 to 30 & $\begin{array}{r}2.7 \\
(0.5)\end{array}$ & $\begin{array}{r}35.6 \\
(5.8)\end{array}$ & $\begin{array}{l}18.7 \\
(4.9)\end{array}$ & $\begin{array}{c}19.7 \\
(4.5)\end{array}$ & $\begin{array}{r}26.0 \\
(5.6)\end{array}$ & 100 & $\begin{array}{r}7.2 \\
(0.7)\end{array}$ & $\begin{array}{r}61.2 \\
(4.9)\end{array}$ & $\begin{array}{l}10.2 \\
(1.8)\end{array}$ & $\begin{array}{l}16.7 \\
(4.7)\end{array}$ & $\begin{array}{r}11.9 \\
\text { (3.3) }\end{array}$ & 100 \\
\hline$>30$ & $\begin{array}{r}3.5 \\
(0.5)\end{array}$ & $\begin{array}{r}50.2 \\
(7.4)\end{array}$ & $\begin{array}{l}10.5 \\
(2.8)\end{array}$ & $\begin{array}{l}15.7 \\
(2.9)\end{array}$ & $\begin{array}{r}23.7 \\
(7.0)\end{array}$ & 100 & $\begin{array}{r}7.9 \\
(0.6)\end{array}$ & $\begin{array}{r}54.5 \\
(4.1)\end{array}$ & $\begin{array}{r}20.8 \\
(3.5)\end{array}$ & $\begin{array}{l}10.2 \\
(1.9)\end{array}$ & $\begin{array}{l}14.5 \\
(2.7)\end{array}$ & 100 \\
\hline & 100 & & & & & & 100 & & & & & \\
\hline
\end{tabular}

Note: Educational attainment categories are based on completed years of schooling: 0-4 (Lowest), 5-8 (Low), 9-12 (Med.), and 13+ (High). Standard errors, in parentheses, are clustered at the community level. 
Figure A2: Individual family trajectories by educational attainment and sex.

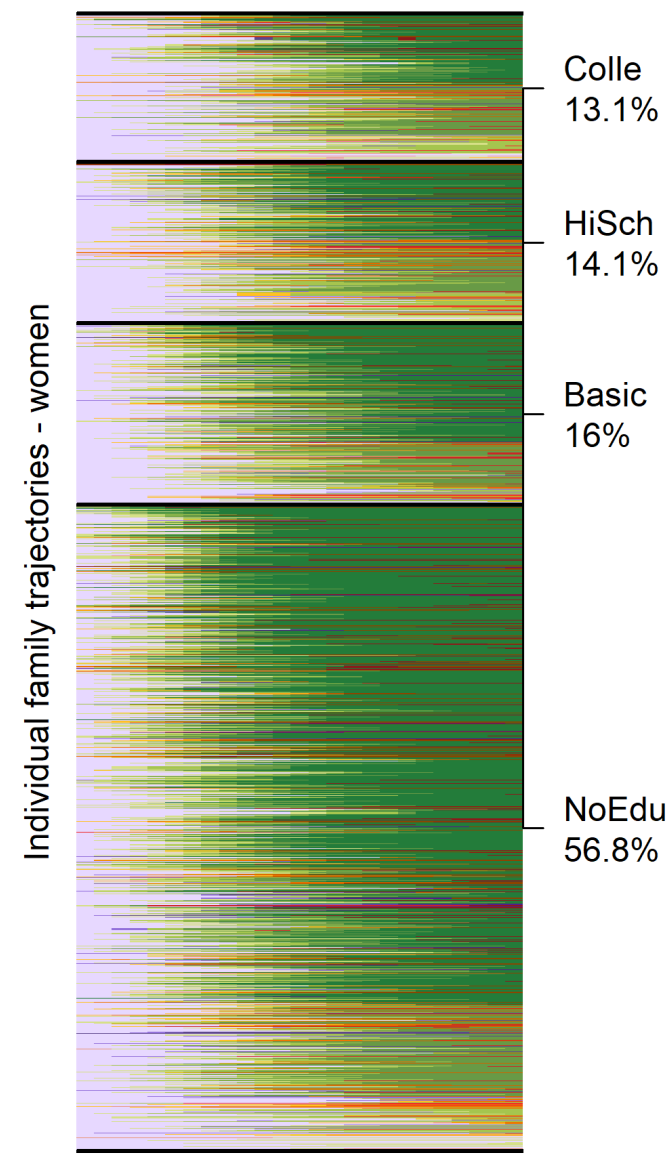

तापातापाताताताताताता

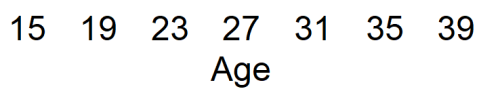

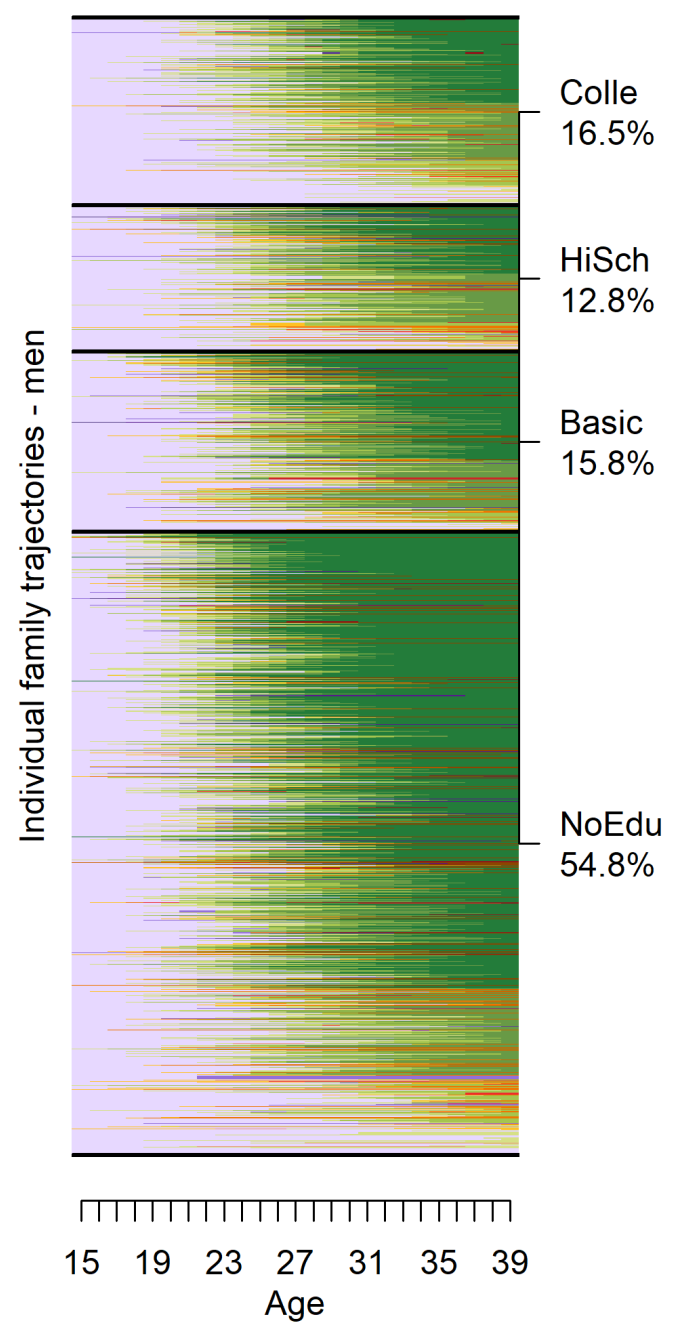

\begin{tabular}{lllll} 
& \multicolumn{3}{c}{ Children } \\
Marital status & 0 & 1 & 2 \\
Never married & & & & \\
Cohabiting \\
Married \\
Div/Sep/Widow
\end{tabular}

Note: Individual trajectories are sorted by completed fertility within each educational attainment category. Educational attainment is coded based on years of schooling as 0-4 (NoEdu), 5-8 (Basic), 9-12 (HiSch), and 13+ (Colle). Even though figures account for sample weights, interpretations should be cautious due to overplotting. 
Figure A3: Individual family trajectories and family typology by sex among household heads.

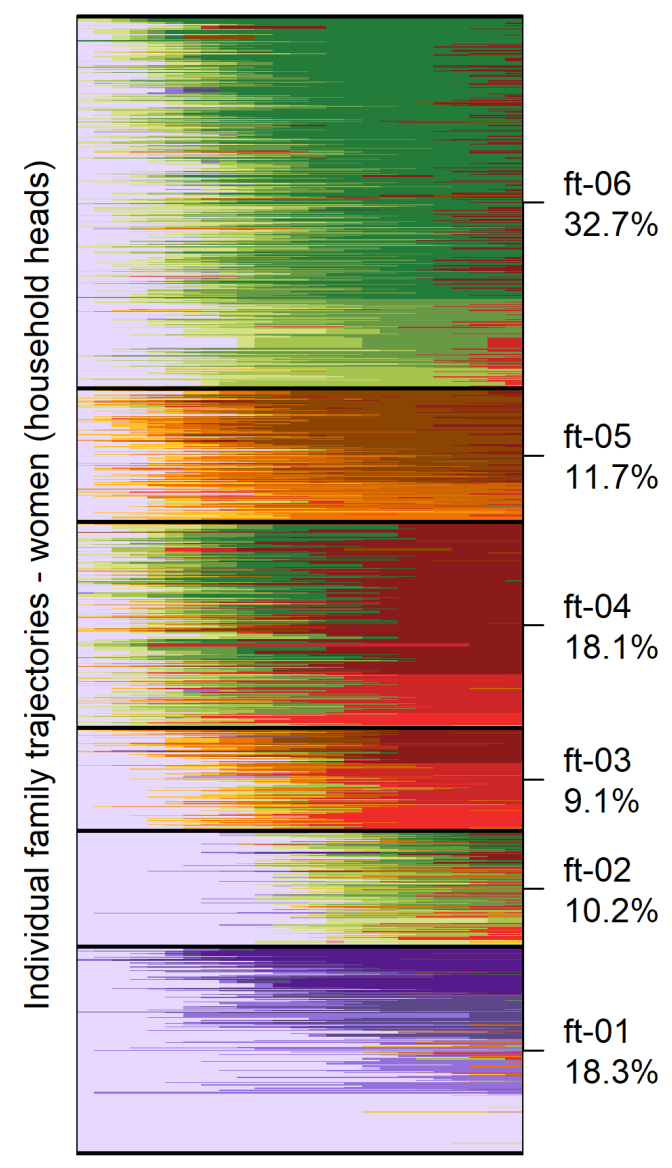

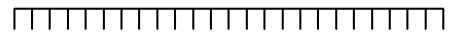

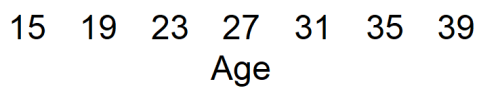

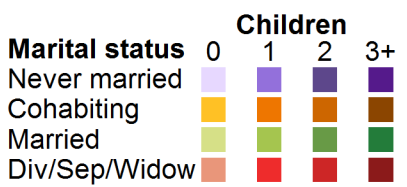

Note: Individual trajectories are sorted by completed fertility within each family category. Even though figures account for sample weights, interpretations should be cautious due to overplotting.

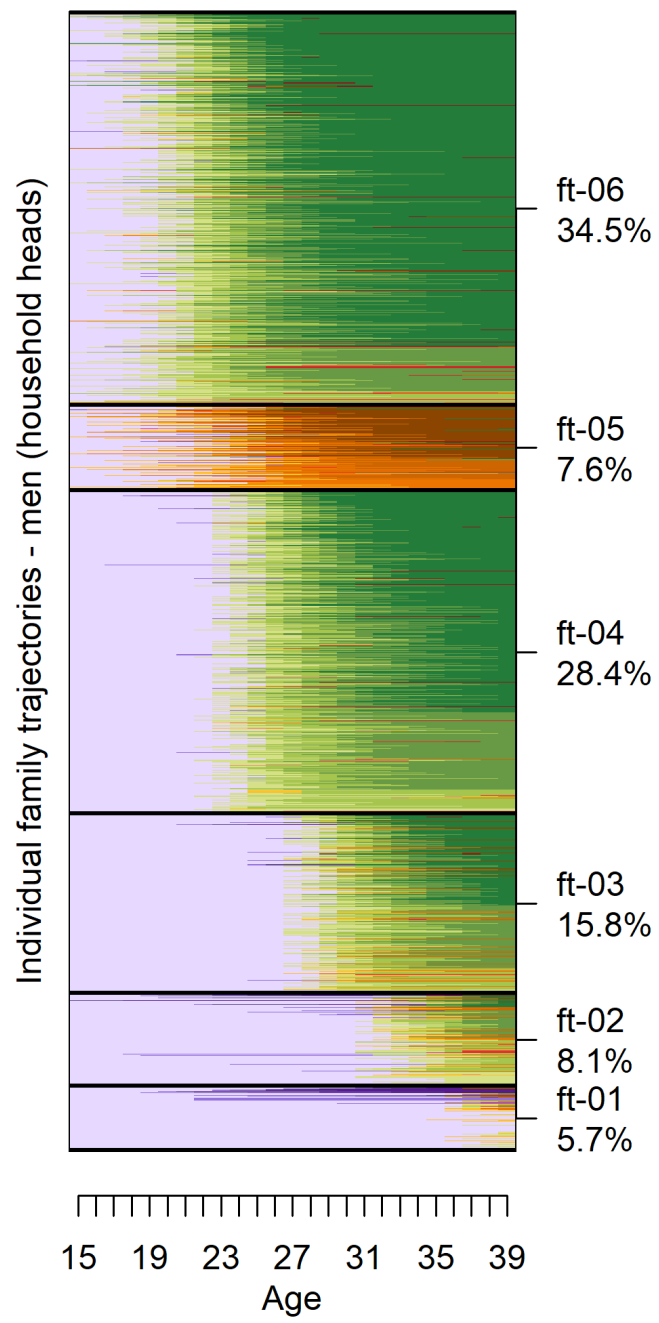


Figure A4: Family profiles' factorial coordinates by type of migration, age at migration, and educational attainment for women (top) and men (bottom) - birth cohorts 1950-69.

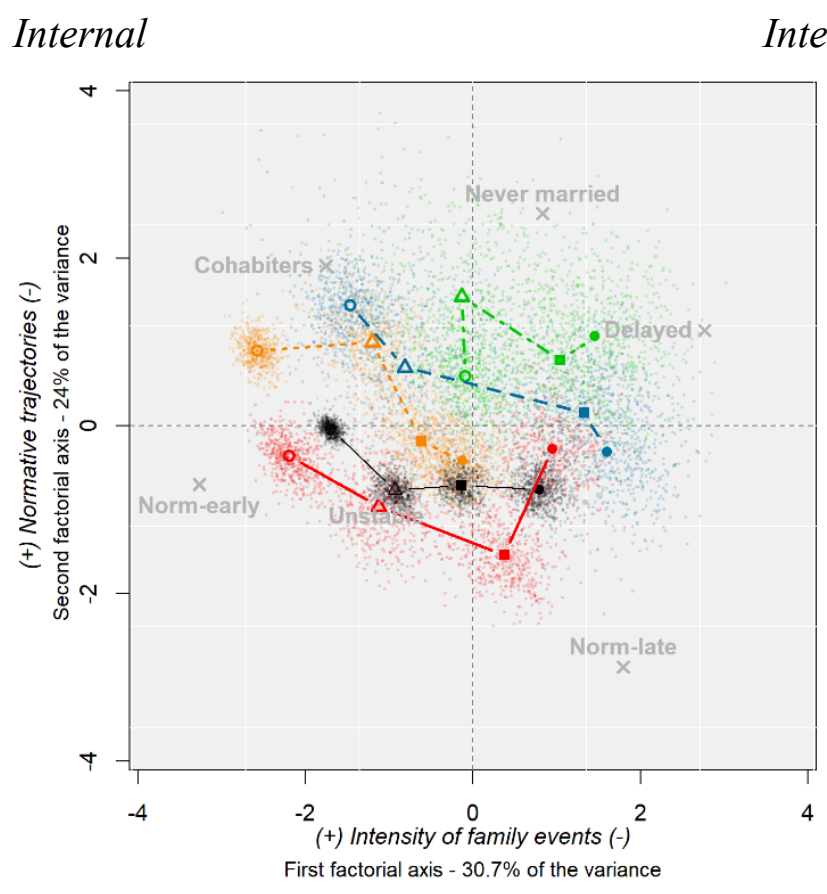

International
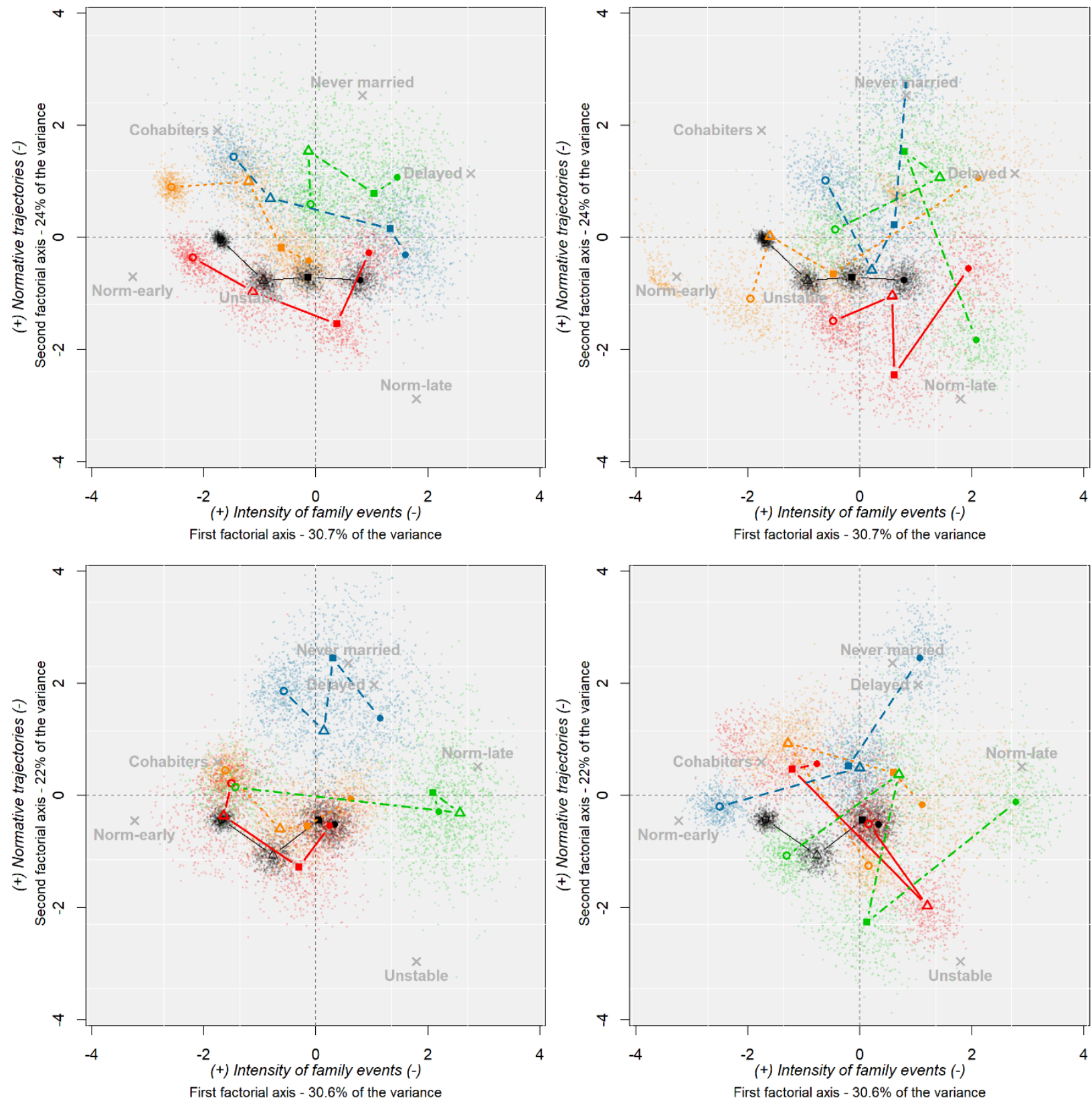

Years of schooling

○-4 $\triangle 5-8 \quad 9-12 \cdot 13+$

\section{Age at migration}

- Non-migrant

$\cdots$ Before age $18-19-24$

$--25-30$

- After age 30

Note: These figures are obtained similarly to Figures 3 and 4, focusing on the 1950-69 birth cohorts. White background lines are separated by one standard deviation. 
Table A3: Predicted probabilities of the family typology (family profiles) by age at migration and educational attainment for women.

\begin{tabular}{|c|c|c|c|c|c|c|c|c|c|c|c|c|c|}
\hline \multirow{2}{*}{\multicolumn{2}{|c|}{ Non-migrant }} & \multicolumn{6}{|c|}{ Family typology } & & & & & & \\
\hline & & Never mamied & \multirow{2}{*}{$\begin{array}{r}\text { Delayed } \\
8.8 \\
(0.5)\end{array}$} & \multirow{2}{*}{$\begin{array}{r}\text { Norm-late } \\
16.8 \\
(0.7)\end{array}$} & \multirow{2}{*}{$\begin{array}{r}\text { Unstable } \\
4.1 \\
(0.4)\end{array}$} & \multirow{2}{*}{$\begin{array}{r}\text { Cohabiters } \\
10.5 \\
(0.6)\end{array}$} & \multirow{2}{*}{$\frac{\text { Norm-early }}{\begin{array}{r}54.5 \\
(10)\end{array}}$} & & & & & & \\
\hline \multirow{4}{*}{$\begin{array}{c}\text { Edu. } \\
\text { attainment }\end{array}$} & Lowest & $\begin{array}{r}5.3 \\
(0.4)\end{array}$ & & & & & & & & & & & \\
\hline & Low & $\begin{array}{r}4.5 \\
(0.7)\end{array}$ & $\begin{array}{r}9.8 \\
(1.0)\end{array}$ & $\begin{array}{l}26.0 \\
(1.5)\end{array}$ & $\begin{array}{r}4.3 \\
(0.7)\end{array}$ & $\begin{array}{r}7.7 \\
(0.9)\end{array}$ & $\begin{array}{l}47.6 \\
(1.7)\end{array}$ & & & & & & \\
\hline & Medium & $\begin{array}{r}8.1 \\
(1.1)\end{array}$ & $\begin{array}{l}13.6 \\
(1.4)\end{array}$ & $\begin{array}{l}27.3 \\
(1.9)\end{array}$ & $\begin{array}{r}5.5 \\
(09)\end{array}$ & $\begin{array}{r}4.7 \\
(0.7)\end{array}$ & $\begin{array}{l}40.8 \\
(20)\end{array}$ & & & & & & \\
\hline & Highest & $\begin{array}{r}7.2 \\
(1.2) \\
\end{array}$ & $\begin{array}{l}21.6 \\
(2.0) \\
\end{array}$ & $\begin{array}{l}31.6 \\
(2.2) \\
\end{array}$ & $\begin{array}{r}2.6 \\
(0.7) \\
\end{array}$ & $\begin{array}{r}4.1 \\
(0.8) \\
\end{array}$ & $\begin{array}{l}32.9 \\
(22) \\
\end{array}$ & & & & & & \\
\hline \multirow{3}{*}{\multicolumn{2}{|c|}{$\begin{array}{l}\text { Age at migration and } \\
\text { educ. attainment }\end{array}$}} & \multicolumn{6}{|c|}{ Domestic migrants } & \multicolumn{6}{|c|}{ International migrants } \\
\hline & & \multicolumn{6}{|c|}{ Family typology } & \multicolumn{6}{|c|}{ Family typology } \\
\hline & & Never married & Delayed & Norm-late & Unstable & Cohabiters & Norm-early & Never married & Debyed & Norm-late & Unstable & Cohabiters & Norm-early \\
\hline \multirow[t]{4}{*}{$<18$} & Lowest & $\begin{array}{r}6.4 \\
(1.0)\end{array}$ & $\begin{array}{r}5.2 \\
(0.9)\end{array}$ & $\begin{array}{r}9.6 \\
(1.2)\end{array}$ & $\begin{array}{r}6.8 \\
(10)\end{array}$ & $\begin{array}{l}18.0 \\
(1.6)\end{array}$ & $\begin{array}{l}53.8 \\
(2.1)\end{array}$ & $\begin{array}{r}1.4 \\
(1.4)\end{array}$ & $\begin{array}{r}5.8 \\
(2.8)\end{array}$ & $\begin{array}{l}17.1 \\
(4.4)\end{array}$ & $\begin{array}{l}13.8 \\
(4.3)\end{array}$ & $\begin{array}{r}5.1 \\
(2.9)\end{array}$ & $\begin{array}{l}56.8 \\
(5.9)\end{array}$ \\
\hline & Low & $\begin{array}{r}8.7 \\
(2.7)\end{array}$ & $\begin{array}{l}17.4 \\
(3.6)\end{array}$ & $\begin{array}{l}12.9 \\
(3.1)\end{array}$ & $\begin{array}{r}4.3 \\
(20)\end{array}$ & $\begin{array}{l}16.0 \\
(3.6)\end{array}$ & $\begin{array}{l}40.6 \\
(4.7)\end{array}$ & $\begin{array}{r}0.0 \\
(0.0)\end{array}$ & $\begin{array}{r}0.0 \\
(0.0)\end{array}$ & $\begin{array}{r}7.7 \\
(4.1)\end{array}$ & $\begin{array}{r}3.2 \\
(3.0)\end{array}$ & $\begin{array}{r}4.8 \\
(3.4)\end{array}$ & $\begin{array}{l}84.3 \\
(5.8)\end{array}$ \\
\hline & Medium & $\begin{array}{r}7.2 \\
(2.1)\end{array}$ & $\begin{array}{l}13.0 \\
(2.9)\end{array}$ & $\begin{array}{l}24.6 \\
(3.8)\end{array}$ & $\begin{array}{r}4.3 \\
(16)\end{array}$ & $\begin{array}{l}11.2 \\
(2.3)\end{array}$ & $\begin{array}{l}39.8 \\
(42)\end{array}$ & $\begin{array}{r}0.0 \\
(0.0)\end{array}$ & $\begin{array}{l}23.1 \\
(6.1)\end{array}$ & $\begin{array}{l}22.2 \\
(5.9)\end{array}$ & $\begin{array}{r}0.0 \\
(0.0)\end{array}$ & $\begin{array}{r}2.6 \\
(2.2)\end{array}$ & $\begin{array}{l}52.1 \\
(7.2)\end{array}$ \\
\hline & Highest & $\begin{array}{r}6.7 \\
(1.8)\end{array}$ & $\begin{array}{l}16.8 \\
(2.9)\end{array}$ & $\begin{array}{l}26.1 \\
(3.5)\end{array}$ & $\begin{array}{r}9.0 \\
(2.1)\end{array}$ & $\begin{array}{r}7.0 \\
(1.7)\end{array}$ & $\begin{array}{l}34.4 \\
(3.7)\end{array}$ & $\begin{array}{r}5.6 \\
(6.1)\end{array}$ & $\begin{array}{r}56.9 \\
(14.0)\end{array}$ & $\begin{array}{l}13.8 \\
(9.9)\end{array}$ & $\begin{array}{r}0.0 \\
(0.0)\end{array}$ & $\begin{array}{r}2.3 \\
(2.8)\end{array}$ & $\begin{array}{r}21.5 \\
(12.0)\end{array}$ \\
\hline \multirow[t]{4}{*}{$19-24$} & Lowest & $\begin{array}{r}6.7 \\
(1.5)\end{array}$ & $\begin{array}{r}4.0 \\
(1.2)\end{array}$ & $\begin{array}{l}17.0 \\
(2.2)\end{array}$ & $\begin{array}{l}10.5 \\
(18)\end{array}$ & $\begin{array}{l}12.2 \\
(2.0)\end{array}$ & $\begin{array}{l}49.6 \\
(3.0)\end{array}$ & $\begin{array}{r}7.3 \\
(2.2)\end{array}$ & $\begin{array}{r}2.9 \\
(1.4)\end{array}$ & $\begin{array}{l}36.6 \\
(4.0)\end{array}$ & $\begin{array}{r}6.4 \\
(2.2)\end{array}$ & $\begin{array}{r}4.3 \\
(1.9)\end{array}$ & $\begin{array}{l}42.5 \\
(4.1)\end{array}$ \\
\hline & Low & $\begin{array}{r}6.0 \\
(2.9)\end{array}$ & $\begin{array}{r}5.7 \\
(2.8)\end{array}$ & $\begin{array}{l}22.7 \\
(5.1)\end{array}$ & $\begin{array}{r}7.2 \\
(32)\end{array}$ & $\begin{array}{r}4.0 \\
(2.2)\end{array}$ & $\begin{array}{l}54.5 \\
(6.1)\end{array}$ & $\begin{array}{r}8.3 \\
(4.5)\end{array}$ & $\begin{array}{r}9.2 \\
(4.5)\end{array}$ & $\begin{array}{l}40.1 \\
(7.5)\end{array}$ & $\begin{array}{r}0.0 \\
(0.0)\end{array}$ & $\begin{array}{r}8.0 \\
(5.1)\end{array}$ & $\begin{array}{l}34.3 \\
(7.2)\end{array}$ \\
\hline & Medium & $\begin{array}{r}6.5 \\
(2.3)\end{array}$ & $\begin{array}{l}10.5 \\
(3.1)\end{array}$ & $\begin{array}{l}40.2 \\
(5.0)\end{array}$ & $\begin{array}{r}4.7 \\
(19)\end{array}$ & $\begin{array}{r}5.1 \\
(1.7)\end{array}$ & $\begin{array}{l}33.0 \\
(48)\end{array}$ & $\begin{array}{r}1.8 \\
(1.7)\end{array}$ & $\begin{array}{l}11.8 \\
(4.4)\end{array}$ & $\begin{array}{l}64.5 \\
(6.6)\end{array}$ & $\begin{array}{r}8.0 \\
(3.3)\end{array}$ & $\begin{array}{r}1.7 \\
(1.1)\end{array}$ & $\begin{array}{l}12.2 \\
(4.6)\end{array}$ \\
\hline & Highest & $\begin{array}{l}11.0 \\
(2.8)\end{array}$ & $\begin{array}{l}21.9 \\
(3.9)\end{array}$ & $\begin{array}{l}33.6 \\
(4.4)\end{array}$ & $\begin{array}{r}5.6 \\
(20)\end{array}$ & $\begin{array}{r}4.6 \\
(1.6)\end{array}$ & $\begin{array}{l}23.4 \\
(40)\end{array}$ & $\begin{array}{r}4.5 \\
(2.5)\end{array}$ & $\begin{array}{l}26.5 \\
(5.6)\end{array}$ & $\begin{array}{l}35.6 \\
(6.1)\end{array}$ & $\begin{array}{r}2.9 \\
(1.9)\end{array}$ & $\begin{array}{r}4.0 \\
(2.0)\end{array}$ & $\begin{array}{l}26.4 \\
(5.6)\end{array}$ \\
\hline \multirow[t]{4}{*}{$25-30$} & Lowest & $\begin{array}{r}8.9 \\
(2.3)\end{array}$ & $\begin{array}{l}20.2 \\
(3.3)\end{array}$ & $\begin{array}{l}23.3 \\
(3.5)\end{array}$ & $\begin{array}{r}6.1 \\
(20)\end{array}$ & $\begin{array}{l}13.2 \\
(2.8)\end{array}$ & $\begin{array}{l}28.3 \\
(3.7)\end{array}$ & $\begin{array}{l}19.8 \\
(4.7)\end{array}$ & $\begin{array}{l}10.2 \\
(3.5)\end{array}$ & $\begin{array}{l}15.2 \\
(4.1)\end{array}$ & $\begin{array}{l}14.4 \\
(4.0)\end{array}$ & $\begin{array}{r}0.0 \\
(0.0)\end{array}$ & $\begin{array}{l}40.4 \\
(5.7)\end{array}$ \\
\hline & Low & $\begin{array}{l}21.1 \\
(7.6)\end{array}$ & $\begin{array}{l}22.3 \\
(7.8)\end{array}$ & $\begin{array}{l}13.1 \\
(6.3)\end{array}$ & $\begin{array}{r}4.1 \\
(3.7)\end{array}$ & $\begin{array}{r}8.8 \\
(5.0)\end{array}$ & $\begin{array}{l}30.6 \\
(8.6)\end{array}$ & $\begin{array}{l}26.8 \\
(7.3)\end{array}$ & $\begin{array}{l}20.2 \\
(6.3)\end{array}$ & $\begin{array}{l}24.5 \\
(6.8)\end{array}$ & $\begin{array}{r}0.0 \\
(0.0)\end{array}$ & $\begin{array}{r}2.8 \\
(2.3)\end{array}$ & $\begin{array}{l}25.7 \\
(7.0)\end{array}$ \\
\hline & Medium & $\begin{array}{r}5.1 \\
(3.2)\end{array}$ & $\begin{array}{l}42.3 \\
(7.7)\end{array}$ & $\begin{array}{l}17.6 \\
(6.1)\end{array}$ & $\begin{array}{r}3.9 \\
(28)\end{array}$ & $\begin{array}{r}6.8 \\
(3.0)\end{array}$ & $\begin{array}{r}24.3 \\
(68)\end{array}$ & $\begin{array}{l}24.8 \\
(7.0)\end{array}$ & $\begin{array}{l}21.9 \\
(6.7)\end{array}$ & $\begin{array}{l}17.3 \\
(6.3)\end{array}$ & $\begin{array}{r}0.0 \\
(0.0)\end{array}$ & $\begin{array}{r}8.2 \\
(3.1)\end{array}$ & $\begin{array}{l}27.8 \\
(7.5)\end{array}$ \\
\hline & Highest & $\begin{array}{r}9.3 \\
(4.5)\end{array}$ & $\begin{array}{l}42.5 \\
(8.0)\end{array}$ & $\begin{array}{l}19.2 \\
(6.5)\end{array}$ & $\begin{array}{r}3.4 \\
(2.7)\end{array}$ & $\begin{array}{r}6.8 \\
\text { (3.4) }\end{array}$ & $\begin{array}{l}18.7 \\
(63)\end{array}$ & $\begin{array}{r}2.3 \\
(1.9)\end{array}$ & $\begin{array}{l}33.3 \\
(6.4)\end{array}$ & $\begin{array}{l}40.6 \\
(6.7)\end{array}$ & $\begin{array}{r}2.9 \\
(1.9)\end{array}$ & $\begin{array}{r}0.8 \\
(0.8)\end{array}$ & $\begin{array}{l}20.0 \\
(5.5)\end{array}$ \\
\hline \multirow[t]{4}{*}{$>30$} & Lowest & $\begin{array}{l}13.1 \\
(2.6)\end{array}$ & $\begin{array}{l}12.5 \\
(2.6)\end{array}$ & $\begin{array}{r}7.7 \\
(2.1)\end{array}$ & $\begin{array}{l}11.1 \\
(25)\end{array}$ & $\begin{array}{l}14.6 \\
(2.9)\end{array}$ & $\begin{array}{l}40.9 \\
\text { (39) }\end{array}$ & $\begin{array}{l}10.5 \\
(2.6)\end{array}$ & $\begin{array}{l}19.2 \\
(3.4)\end{array}$ & $\begin{array}{l}10.3 \\
(2.6)\end{array}$ & $\begin{array}{l}12.6 \\
(2.8)\end{array}$ & $\begin{array}{l}11.1 \\
(2.8)\end{array}$ & $\begin{array}{l}36.3 \\
(4.1)\end{array}$ \\
\hline & Low & $\begin{array}{l}23.3 \\
(8.1)\end{array}$ & $\begin{array}{l}12.2 \\
(6.0)\end{array}$ & $\begin{array}{l}15.1 \\
(6.4)\end{array}$ & $\begin{array}{r}2.6 \\
(3.1)\end{array}$ & $\begin{array}{r}8.5 \\
(5.5)\end{array}$ & $\begin{array}{l}38.3 \\
(89)\end{array}$ & $\begin{array}{r}6.1 \\
(4.3)\end{array}$ & $\begin{array}{l}19.7 \\
(7.4)\end{array}$ & $\begin{array}{l}23.6 \\
(7.8)\end{array}$ & $\begin{array}{l}18.2 \\
(7.3)\end{array}$ & $\begin{array}{r}5.5 \\
(4.4)\end{array}$ & $\begin{array}{l}27.0 \\
(8.2)\end{array}$ \\
\hline & Medium & $\begin{array}{l}15.3 \\
(5.1)\end{array}$ & $\begin{array}{l}22.3 \\
(6.1)\end{array}$ & $\begin{array}{l}31.6 \\
(6.9)\end{array}$ & $\begin{array}{r}0.0 \\
(0.0)\end{array}$ & $\begin{array}{r}7.8 \\
(3.2)\end{array}$ & $\begin{array}{l}22.9 \\
(63)\end{array}$ & $\begin{array}{l}15.9 \\
(5.5)\end{array}$ & $\begin{array}{l}19.3 \\
(6.2)\end{array}$ & $\begin{array}{l}18.3 \\
(6.3)\end{array}$ & $\begin{array}{r}7.7 \\
(3.7)\end{array}$ & $\begin{array}{r}5.7 \\
(2.6)\end{array}$ & $\begin{array}{l}33.0 \\
(7.6)\end{array}$ \\
\hline & Highest & $\begin{array}{l}11.3 \\
(4.5)\end{array}$ & $\begin{array}{l}27.0 \\
(7.0)\end{array}$ & $\begin{array}{l}33.0 \\
(7.5)\end{array}$ & $\begin{array}{r}4.6 \\
(3.0)\end{array}$ & $\begin{array}{r}5.9 \\
(2.9)\end{array}$ & $\begin{array}{l}18.1 \\
(6.1)\end{array}$ & $\begin{array}{l}33.0 \\
(6.0)\end{array}$ & $\begin{array}{l}12.5 \\
(4.4)\end{array}$ & $\begin{array}{l}33.6 \\
(6.5)\end{array}$ & $\begin{array}{r}5.7 \\
(2.6)\end{array}$ & $\begin{array}{r}2.8 \\
(1.4)\end{array}$ & $\begin{array}{l}12.3 \\
(4.5)\end{array}$ \\
\hline
\end{tabular}

Note: Standard errors, in parentheses, are clustered at the community level. 
Table A4: Predicted probabilities of the family typology (family profiles) by age at migration and educational attainment for men.

\begin{tabular}{|c|c|c|c|c|c|c|c|c|c|c|c|c|c|}
\hline \multirow{2}{*}{\multicolumn{2}{|c|}{ Non-migrant }} & \multicolumn{6}{|c|}{ Family typobgy } & & & & & & \\
\hline & & Never married & \multirow{2}{*}{$\begin{array}{r}\text { Latest } \\
6.4 \\
(0.6)\end{array}$} & \multirow{2}{*}{$\begin{array}{r}\text { Delaved } \\
8.9 \\
(0.7)\end{array}$} & \multirow{2}{*}{$\begin{array}{r}\text { Norm-late } \\
\begin{array}{r}20.0 \\
(1.0)\end{array}\end{array}$} & \multirow{2}{*}{$\begin{array}{r}\text { Cohabiters } \\
10.1 \\
(0.7)\end{array}$} & \multirow{2}{*}{$\frac{\text { Norm-early }}{50.0}$} & & & & & & \\
\hline \multirow{4}{*}{$\begin{array}{c}\text { Edu. } \\
\text { attainment }\end{array}$} & Lowest & $\begin{array}{r}4.6 \\
(0.5)\end{array}$ & & & & & & & & & & & \\
\hline & Low & $\begin{array}{r}4.1 \\
(0.9)\end{array}$ & $\begin{array}{r}6.1 \\
(1.0)\end{array}$ & $\begin{array}{l}12.2 \\
(1.4)\end{array}$ & $\begin{array}{l}29.2 \\
(2.0)\end{array}$ & $\begin{array}{r}5.0 \\
(09)\end{array}$ & $\begin{array}{l}43.5 \\
(2.1)\end{array}$ & & & & & & \\
\hline & Medium & $\begin{array}{r}7.3 \\
(1.2)\end{array}$ & $\begin{array}{r}7.1 \\
(1.1)\end{array}$ & $\begin{array}{l}15.5 \\
(1.7)\end{array}$ & $\begin{array}{l}30.1 \\
(2.2)\end{array}$ & $\begin{array}{r}5.0 \\
(08)\end{array}$ & $\begin{array}{l}35.0 \\
(2.3)\end{array}$ & & & & & & \\
\hline & Highest & $\begin{array}{r}5.4 \\
(1.0) \\
\end{array}$ & $\begin{array}{r}9.3 \\
(1.2) \\
\end{array}$ & $\begin{array}{l}20.9 \\
(1.9)\end{array}$ & $\begin{array}{l}28.1 \\
(2.1) \\
\end{array}$ & $\begin{array}{r}3.0 \\
(0.6) \\
\end{array}$ & $\begin{array}{r}33.3 \\
(2.2) \\
\end{array}$ & & & & & & \\
\hline \multirow{3}{*}{\multicolumn{2}{|c|}{$\begin{array}{l}\text { Age at migration and } \\
\text { educ. attainment }\end{array}$}} & \multicolumn{6}{|c|}{ Domestic migrants } & \multicolumn{6}{|c|}{ International migrants } \\
\hline & & \multicolumn{6}{|c|}{ Family typobgy } & \multicolumn{6}{|c|}{ Family typology } \\
\hline & & Never married & Latest & Delayed & Norm-late & Cohabiters & Norm-early & Never married & Latest & Delayed & Norm-late & Cohabiters & Norm-early \\
\hline \multirow[t]{4}{*}{$<18$} & Lowest & $\begin{array}{r}7.3 \\
(1.2)\end{array}$ & $\begin{array}{r}9.7 \\
(1.4)\end{array}$ & $\begin{array}{r}9.7 \\
(1.4)\end{array}$ & $\begin{array}{l}15.5 \\
(1.7)\end{array}$ & $\begin{array}{l}10.7 \\
(15)\end{array}$ & $\begin{array}{l}47.1 \\
(2.4)\end{array}$ & $\begin{array}{r}6.4 \\
(16)\end{array}$ & $\begin{array}{r}4.9 \\
(1.4)\end{array}$ & $\begin{array}{l}11.1 \\
(19)\end{array}$ & $\begin{array}{l}29.2 \\
(2.8)\end{array}$ & $\begin{array}{r}3.1 \\
(1.1)\end{array}$ & $\begin{array}{l}45.4 \\
(3.0)\end{array}$ \\
\hline & Low & $\begin{array}{r}3.8 \\
(1.8)\end{array}$ & $\begin{array}{r}8.8 \\
(2.6)\end{array}$ & $\begin{array}{r}9.3 \\
(2.6)\end{array}$ & $\begin{array}{l}29.4 \\
(4.0)\end{array}$ & $\begin{array}{l}10.7 \\
(28)\end{array}$ & $\begin{array}{l}38.0 \\
(4.3)\end{array}$ & $\begin{array}{r}5.9 \\
(2.7)\end{array}$ & $\begin{array}{r}8.8 \\
(3.1)\end{array}$ & $\begin{array}{l}15.1 \\
(40)\end{array}$ & $\begin{array}{l}12.9 \\
(3.7)\end{array}$ & $\begin{array}{r}4.1 \\
(2.0)\end{array}$ & $\begin{array}{l}53.2 \\
(5.4)\end{array}$ \\
\hline & Medium & $\begin{array}{r}6.6 \\
(2.2)\end{array}$ & $\begin{array}{r}9.2 \\
(2.5)\end{array}$ & $\begin{array}{l}15.0 \\
(3.4)\end{array}$ & $\begin{array}{l}28.1 \\
(4.3)\end{array}$ & $\begin{array}{r}6.9 \\
(19)\end{array}$ & $\begin{array}{l}34.3 \\
(4.6)\end{array}$ & $\begin{array}{r}0.0 \\
(0.0)\end{array}$ & $\begin{array}{l}16.7 \\
(5.4)\end{array}$ & $\begin{array}{l}23.1 \\
(59)\end{array}$ & $\begin{array}{l}42.0 \\
(6.8)\end{array}$ & $\begin{array}{r}0.0 \\
(0.0)\end{array}$ & $\begin{array}{l}18.2 \\
(5.3)\end{array}$ \\
\hline & Highest & $\begin{array}{r}7.8 \\
(1.8)\end{array}$ & $\begin{array}{r}8.4 \\
(1.9)\end{array}$ & $\begin{array}{l}22.2 \\
(3.1)\end{array}$ & $\begin{array}{l}26.1 \\
(3.3)\end{array}$ & $\begin{array}{r}2.6 \\
(09)\end{array}$ & $\begin{array}{l}32.9 \\
(3.6)\end{array}$ & $\begin{array}{l}11.2 \\
(42)\end{array}$ & $\begin{array}{r}0.6 \\
(1.0)\end{array}$ & $\begin{array}{l}37.2 \\
(6.4)\end{array}$ & $\begin{array}{l}21.4 \\
(5.4)\end{array}$ & $\begin{array}{r}6.9 \\
(3.0)\end{array}$ & $\begin{array}{l}22.7 \\
(5.5)\end{array}$ \\
\hline \multirow[t]{4}{*}{$19-24$} & Lowest & $\begin{array}{r}6.8 \\
(1.5)\end{array}$ & $\begin{array}{r}7.9 \\
(1.7)\end{array}$ & $\begin{array}{r}6.5 \\
(1.4)\end{array}$ & $\begin{array}{l}17.0 \\
(2.2)\end{array}$ & $\begin{array}{r}8.4 \\
(18)\end{array}$ & $\begin{array}{l}53.4 \\
\text { (3.0) }\end{array}$ & $\begin{array}{r}5.4 \\
(10)\end{array}$ & $\begin{array}{r}5.1 \\
(1.1)\end{array}$ & $\begin{array}{l}20.3 \\
(18)\end{array}$ & $\begin{array}{l}28.1 \\
(2.0)\end{array}$ & $\begin{array}{r}5.0 \\
(1.1)\end{array}$ & $\begin{array}{l}36.1 \\
(2.1)\end{array}$ \\
\hline & Low & $\begin{array}{r}2.9 \\
(2.1)\end{array}$ & $\begin{array}{r}5.7 \\
(3.0)\end{array}$ & $\begin{array}{r}4.5 \\
(2.7)\end{array}$ & $\begin{array}{l}25.0 \\
(5.6)\end{array}$ & $\begin{array}{r}6.6 \\
(30)\end{array}$ & $\begin{array}{l}55.4 \\
(6.5)\end{array}$ & $\begin{array}{r}8.3 \\
(2.4)\end{array}$ & $\begin{array}{r}4.6 \\
(1.8)\end{array}$ & $\begin{array}{l}12.5 \\
(2.7)\end{array}$ & $\begin{array}{l}51.3 \\
(4.1)\end{array}$ & $\begin{array}{r}5.7 \\
(2.0)\end{array}$ & $\begin{array}{l}17.6 \\
(3.0)\end{array}$ \\
\hline & Medium & $\begin{array}{r}2.8 \\
(1.7)\end{array}$ & $\begin{array}{r}3.2 \\
(1.8)\end{array}$ & $\begin{array}{l}10.9 \\
(3.4)\end{array}$ & $\begin{array}{l}43.6 \\
(5.5)\end{array}$ & $\begin{array}{r}7.5 \\
(25)\end{array}$ & $\begin{array}{l}32.0 \\
(5.2)\end{array}$ & $\begin{array}{r}2.6 \\
(18)\end{array}$ & $\begin{array}{r}6.8 \\
(2.8)\end{array}$ & $\begin{array}{l}21.8 \\
(49)\end{array}$ & $\begin{array}{l}12.3 \\
(3.9)\end{array}$ & $\begin{array}{r}6.0 \\
(2.3)\end{array}$ & $\begin{array}{l}50.6 \\
(5.9)\end{array}$ \\
\hline & Highest & $\begin{array}{r}2.2 \\
(1.0)\end{array}$ & $\begin{array}{l}11.4 \\
(2.2)\end{array}$ & $\begin{array}{l}18.7 \\
(2.8)\end{array}$ & $\begin{array}{l}29.7 \\
(3.3)\end{array}$ & $\begin{array}{r}4.6 \\
(13)\end{array}$ & $\begin{array}{l}33.4 \\
(3.4)\end{array}$ & $\begin{array}{l}20.1 \\
(40)\end{array}$ & $\begin{array}{r}2.9 \\
(1.5)\end{array}$ & $\begin{array}{l}12.9 \\
(35)\end{array}$ & $\begin{array}{l}30.9 \\
(4.7)\end{array}$ & $\begin{array}{r}0.5 \\
(0.5)\end{array}$ & $\begin{array}{l}32.7 \\
(4.8)\end{array}$ \\
\hline \multirow[t]{4}{*}{$25-30$} & Lowest & $\begin{array}{r}3.4 \\
(1.4)\end{array}$ & $\begin{array}{l}13.2 \\
(2.8)\end{array}$ & $\begin{array}{r}7.3 \\
(1.9)\end{array}$ & $\begin{array}{l}23.9 \\
(3.3)\end{array}$ & $\begin{array}{r}9.6 \\
(25)\end{array}$ & $\begin{array}{l}42.6 \\
(3.9)\end{array}$ & $\begin{array}{l}10.9 \\
(1.7)\end{array}$ & $\begin{array}{r}5.0 \\
(1.2)\end{array}$ & $\begin{array}{r}8.8 \\
(15)\end{array}$ & $\begin{array}{l}21.1 \\
(2.2)\end{array}$ & $\begin{array}{r}2.7 \\
(0.9)\end{array}$ & $\begin{array}{l}51.4 \\
(2.7)\end{array}$ \\
\hline & Low & $\begin{array}{r}3.0 \\
(2.6)\end{array}$ & $\begin{array}{r}8.7 \\
(4.2)\end{array}$ & $\begin{array}{l}34.3 \\
(7.2)\end{array}$ & $\begin{array}{l}33.3 \\
(7.2)\end{array}$ & $\begin{array}{r}2.2 \\
(19)\end{array}$ & $\begin{array}{l}18.5 \\
(5.9)\end{array}$ & $\begin{array}{l}21.5 \\
(5 s)\end{array}$ & $\begin{array}{l}10.4 \\
(4.1)\end{array}$ & $\begin{array}{l}15.3 \\
(4.7)\end{array}$ & $\begin{array}{l}24.9 \\
(5.6)\end{array}$ & $\begin{array}{r}2.3 \\
(1.9)\end{array}$ & $\begin{array}{l}25.6 \\
(5.6)\end{array}$ \\
\hline & Medium & $\begin{array}{r}4.6 \\
(3.1)\end{array}$ & $\begin{array}{l}19.8 \\
(6.1)\end{array}$ & $\begin{array}{l}21.3 \\
(6.8)\end{array}$ & $\begin{array}{l}36.9 \\
(7.8)\end{array}$ & $\begin{array}{r}5.6 \\
(29)\end{array}$ & $\begin{array}{l}11.9 \\
(5.5)\end{array}$ & $\begin{array}{r}2.2 \\
(1.1)\end{array}$ & $\begin{array}{r}2.0 \\
(1.1)\end{array}$ & $\begin{array}{l}29.0 \\
(50)\end{array}$ & $\begin{array}{l}44.9 \\
(5.5)\end{array}$ & $\begin{array}{r}1.2 \\
\langle 0.6\rangle\end{array}$ & $\begin{array}{l}20.7 \\
(4.5)\end{array}$ \\
\hline & Highest & $\begin{array}{r}8.7 \\
(3.3)\end{array}$ & $\begin{array}{r}8.8 \\
(3.4)\end{array}$ & $\begin{array}{l}37.0 \\
(6.1)\end{array}$ & $\begin{array}{l}30.0 \\
(5.8)\end{array}$ & $\begin{array}{r}3.7 \\
(19)\end{array}$ & $\begin{array}{l}11.9 \\
(4.2)\end{array}$ & $\begin{array}{r}3.7 \\
(20)\end{array}$ & $\begin{array}{l}10.2 \\
(3.3)\end{array}$ & $\begin{array}{l}43.4 \\
(6.1)\end{array}$ & $\begin{array}{l}31.6 \\
(5.7)\end{array}$ & $\begin{array}{r}0.0 \\
(0.0)\end{array}$ & $\begin{array}{l}11.1 \\
(4.1)\end{array}$ \\
\hline \multirow[t]{4}{*}{$>30$} & Lowest & $\begin{array}{r}6.9 \\
(1.6)\end{array}$ & $\begin{array}{l}16.9 \\
(2.6)\end{array}$ & $\begin{array}{r}7.7 \\
(1.7)\end{array}$ & $\begin{array}{l}16.8 \\
(2.4)\end{array}$ & $\begin{array}{r}6.9 \\
(18)\end{array}$ & $\begin{array}{l}44.8 \\
(3.3)\end{array}$ & $\begin{array}{r}3.7 \\
(10)\end{array}$ & $\begin{array}{r}5.3 \\
(1.3)\end{array}$ & $\begin{array}{l}11.3 \\
(1.7)\end{array}$ & $\begin{array}{l}14.3 \\
(1.9)\end{array}$ & $\begin{array}{r}7.8 \\
(1.5)\end{array}$ & $\begin{array}{l}57.6 \\
(2.7)\end{array}$ \\
\hline & Low & $\begin{array}{r}9.7 \\
(4.0)\end{array}$ & $\begin{array}{l}15.7 \\
(4.9)\end{array}$ & $\begin{array}{l}15.1 \\
(4.7)\end{array}$ & $\begin{array}{l}21.1 \\
(5.4)\end{array}$ & $\begin{array}{r}5.5 \\
(29)\end{array}$ & $\begin{array}{l}32.9 \\
(6.2)\end{array}$ & $\begin{array}{l}12.3 \\
(30)\end{array}$ & $\begin{array}{r}9.5 \\
(2.6)\end{array}$ & $\begin{array}{l}14.0 \\
(3.1)\end{array}$ & $\begin{array}{l}21.9 \\
\text { (3.6) }\end{array}$ & $\begin{array}{r}5.4 \\
(1.9)\end{array}$ & $\begin{array}{l}36.9 \\
(4.2)\end{array}$ \\
\hline & Medium & $\begin{array}{l}24.8 \\
(6.8)\end{array}$ & $\begin{array}{r}9.3 \\
(4.4)\end{array}$ & $\begin{array}{l}13.0 \\
(5.4)\end{array}$ & $\begin{array}{l}23.9 \\
(6.8)\end{array}$ & $\begin{array}{r}2.6 \\
(2.1)\end{array}$ & $\begin{array}{l}26.4 \\
(7.2)\end{array}$ & $\begin{array}{l}10.1 \\
(36)\end{array}$ & $\begin{array}{l}13.1 \\
(4.0)\end{array}$ & $\begin{array}{r}8.0 \\
(3.6)\end{array}$ & $\begin{array}{l}26.4 \\
(5.7)\end{array}$ & $\begin{array}{r}9.7 \\
(3.0)\end{array}$ & $\begin{array}{l}32.7 \\
(6.3)\end{array}$ \\
\hline & Highest & $\begin{array}{r}8.9 \\
(3.3)\end{array}$ & $\begin{array}{l}16.1 \\
(4.4)\end{array}$ & $\begin{array}{l}33.7 \\
(5.6)\end{array}$ & $\begin{array}{l}19.9 \\
(4.8)\end{array}$ & $\begin{array}{r}2.2 \\
(16)\end{array}$ & $\begin{array}{l}19.1 \\
(4.8)\end{array}$ & $\begin{array}{l}23.6 \\
(45)\end{array}$ & $\begin{array}{l}12.2 \\
(3.2)\end{array}$ & $\begin{array}{l}22.1 \\
(4.6)\end{array}$ & $\begin{array}{l}16.9 \\
(4.1)\end{array}$ & $\begin{array}{r}6.4 \\
(2.0)\end{array}$ & $\begin{array}{l}18.8 \\
(4.4)\end{array}$ \\
\hline
\end{tabular}

Note: Standard errors, in parentheses, are clustered at the community level. 